\title{
Comparison of Continuous and Filter-Based Carbon Measurements at the Fresno Supersite
}

\author{
Kihong Park, Judith C. Chow, John G. Watson, Dana L. Trimble, and Prakash Doraiswamy \\ Desert Research Institute, Reno, NV
}

\author{
Kihong Park \\ Gwangju Institute of Science and Technology, Gwangju, Korea
}

\author{
W. Pat Arnott \\ University of Nevada, Reno, NV
}

Kenneth R. Stroud, Kenneth Bowers, and Richard Bode

California Air Resources Board, Sacramento, CA

\author{
Andre Petzold \\ Deutsches Zentrum fur Luft- und Raumfahrt Oberpfaffenhofen, Institut fur Physik \\ der Atmosphare, Wessling, Germany \\ Anthony D.A. Hansen \\ Lawrence Berkeley National Laboratory, Berkeley, CA
}

\begin{abstract}
Results from six continuous and semicontinuous black carbon (BC) and elemental carbon (EC) measurement methods are compared for ambient samples collected from December 2003 through November 2004 at the Fresno Supersite in California. Instruments included a multi-angle absorption photometer (MAAP; $\lambda=670 \mathrm{~nm}$ ); a dual-wavelength $(\lambda=370$ and $880 \mathrm{~nm})$ aethalometer; seven-color $(\lambda=370,470,520,590,660,880$, and 950 $\mathrm{nm}$ ) aethalometers; the Sunset Laboratory carbon aerosol analysis field instrument; a photoacoustic light absorption analyzer $(\lambda=1047 \mathrm{~nm})$; and the R\&P 5400 ambient carbon particulate monitor. All of these acquired BC or EC measurements over periods of $1 \mathrm{~min}$ to $1 \mathrm{hr}$. Twenty-fourhour integrated filter samples were also acquired and analyzed by the Interagency Monitoring of Protected Visual Environments (IMPROVE) thermal/optical reflectance
\end{abstract}

\section{IMPLICATIONS}

BC can be measured in situ and continuously by optical, thermal, and photoacoustic methods. The results of these measurements are highly correlated but have different absolute values. Relationships differ with changes in the sampled particles (e.g., winter vs summer). Both light- and mass-absorption efficiencies convert light absorption (i.e., the Angstrom Power Law $\left[\lambda^{-\alpha}\right]$, assuming $\alpha=1$ ) to $B C$, and both are wavelength dependent. The assumption that these efficiencies scale with inverse wavelength is not true at the Fresno Supersite and probably not at other locations. carbon analysis protocol. Site-specific mass absorption efficiencies estimated by comparing light absorption with IMPROVE EC concentrations were $5.5 \mathrm{~m}^{2} / \mathrm{g}$ for the MAAP, $10 \mathrm{~m}^{2} / \mathrm{g}$ for the aethalometer at a wavelength of $880 \mathrm{~nm}$, and $2.3 \mathrm{~m}^{2} / \mathrm{g}$ for the photoacoustic analyzer; these differed from the default efficiencies of $6.5,16.6$, and $5 \mathrm{~m}^{2} / \mathrm{g}$, respectively. Scaling absorption by inverse wavelength did not provide equivalent light absorption coefficients among the instruments for the Fresno aerosol measurements. Ratios of light absorption at $370 \mathrm{~nm}$ to those at $880 \mathrm{~nm}$ from the aethalometer were nearly twice as high in winter as in summer. This is consistent with wintertime contributions from vehicle exhaust and from residential wood combustion, which is believed to absorb more shorter-wavelength light. To reconcile BC and EC measurements obtained by different methods, a better understanding is needed of the wavelength dependence of light-absorption and mass-absorption efficiencies and how they vary with different aerosol composition.

\section{INTRODUCTION}

Black carbon (BC), or elemental carbon (EC), particles originate mostly from incomplete combustion of fuels and are major contributors to aerosol light absorption $\left(b_{\text {abs }}\right.$, units of inverse megameters $\left.\left[\mathrm{Mm}^{-1}\right]\right)$ in exhaust emissions and ambient air. Both $\mathrm{BC}$ and $\mathrm{EC}$ affect visibility, health, and the earth's radiation balance. ${ }^{1-6}$ The terms BC, EC, light-absorbing carbon, and soot have been used interchangeably by many researchers, depending on the material sampled, the method used for quantification, and the uses of the data. This imprecise usage, coupled 
with method-dependent definitions for BC or EC, has resulted in much confusion about their comparability. ${ }^{5}$

The most commonly used methods for determining BC and EC extract particles from the air onto a filter, followed by optical and/or thermal analyses. ${ }^{5}$ In optical methods, the attenuation of light $\left(b_{\text {abs }}\right)$ with wavelength ( $\lambda$ ) reflected from, or transmitted through, the particle deposit relative to the blank filter is used to estimate $b_{\text {abs }}(\lambda)$. The $b_{\text {abs }}(\lambda)$ is divided by a mass absorption efficiency, $\sigma_{\text {abs }}(\lambda)$ (units of $\mathrm{m}^{2} / \mathrm{g}$ ), to obtain the BC concentration in $\mu \mathrm{g} / \mathrm{m}^{3}$. The wavelength dependence for $b_{\mathrm{abs}}$ and $\sigma_{\mathrm{abs}}$ is often scaled as $\lambda^{-1}$, following the Angstrom Power Law $\left(\lambda^{\alpha}\right)$ where $\alpha=1$, but $\alpha$ depends on the chemical and physical properties of the sampled aerosol and the filter medium. Kirchstetter et al. ${ }^{7}$ found that the $\lambda^{-1}$ scaling approximated the behavior of fresh vehicle exhaust, but that a $\lambda^{-2}$ scaling was more appropriate for biomass burning aerosol.

In addition to $\lambda$, light scattering in the filter medium, light-scattering particles deposited on the filter, and filter loading influence the accurate determination of BC concentrations. ${ }^{6,8-10}$ Fuller et al. ${ }^{11}$ and Martins et al. ${ }^{12}$ applied advanced optical models to different particle compositions, sizes, and shapes to estimate $\sigma_{\mathrm{abs}}$ ranging from 2 to $30 \mathrm{~m}^{2} / \mathrm{g}$. Empirical measurements of $\sigma_{\mathrm{abs}}$ have been reported in a range of 2 to $17 \mathrm{~m}^{2} / \mathrm{g} \cdot{ }^{6,13}$ Bond and Bergstrom $^{14}$ suggested a $\sigma_{\text {abs }}(550 \mathrm{~nm})$ of $7.5 \pm 1.2 \mathrm{~m}^{2} / \mathrm{g}$ for freshly emitted particles.

In thermal methods for measuring EC, the filter is heated so that carbon evolves at specified temperatures in both nonoxidizing and oxidizing carrier gases. These methods are intended to separate organic carbon (OC) from EC. Carbonate carbon, typically in the form of calcite $\left(\mathrm{CaCO}_{3}\right)$, may also be classified as OC or EC at high temperatures $\left(>800^{\circ} \mathrm{C}\right)$, but it is found only when erosion of non-weathered crustal material is a large contributor to the sample. ${ }^{15,16}$ Although EC will combust in an oxidizing atmosphere, it is stable at high temperatures $\left(<700^{\circ} \mathrm{C}\right)$ in inert atmospheres (e.g., helium [He]).

Some thermal methods use optical monitoring to correct for the charring of $\mathrm{OC}$ to $\mathrm{EC}$ in nonoxidizing atmospheres. Different temperature and charring-correction protocols have resulted in different values of EC even within the same thermal evolution method. ${ }^{17,18}$ Currie et al. ${ }^{19}$ found that the lowest and highest EC reported by different laboratories for the same standard filter sample differed by a factor of 7 .

Photoacoustic detection ${ }^{20-22}$ measures $b_{\text {abs }}(\lambda)$ on particles that have not been changed by filter collection. The photoacoustic analyzer draws particle-laden air into an acoustic resonator through which a high-intensity, modulated, monochromatic light beam is directed. A sound wave is produced at the modulation frequency by expansion of the air when particles absorb energy from light. Matching the modulation frequency to the resonator frequency reinforces the acoustic wave for measurement with a sensitive microphone; $b_{\mathrm{abs}}(\lambda)$ is proportional to the sound energy, and particle absorption is divided by an empirically derived $\sigma_{\mathrm{abs}}(\lambda)$ to attain a BC concentration.

Recent studies have compared and evaluated several current optical, thermal, and photoacoustic BC and EC measurement methods under controlled laboratory conditions. ${ }^{23-26}$ Saathoff et al. ${ }^{24}$ generated diesel soot, graphite electric arc soot, organic-coated soot, and mixtures of soot and ammonium sulfate during the Aerosols, Interactions and Dynamics in the Atmosphere (AIDA) soot aerosol campaign in 1999. They found that optical methods required different $\sigma_{\mathrm{abs}}(\lambda)$ for diesel-soot and arc-soot aerosols to determine BC concentrations. The $\sigma_{\text {abs }}(\lambda)$ determined by optical techniques varied depending on the source type, wavelengths used, and measurement method. Schnaiter et al. ${ }^{25}$ reported a $\sigma_{\text {abs }}(450 \mathrm{~nm})$ value of $10.6 \mathrm{~m}^{2} / \mathrm{g}$ for diesel soot and $5.6 \mathrm{~m}^{2} / \mathrm{g}$ for the graphite electric arc generator. The difference was attributed to different particle structures. These experiments showed higher a $\sigma_{\text {abs }}(450 \mathrm{~nm})$ for coated $\mathrm{BC}$ particles, similar to the theoretical findings of Fuller et al. ${ }^{11}$ Sheridan et al. ${ }^{26}$ used laboratory-generated diesel soot and kerosene and found reasonable agreements among (1) photoacoustic $b_{\text {abs }}(532 \mathrm{~nm}) ;(2)$ the difference between particle light extinction and scattering; and (3) filter-based $b_{\text {abs }}$.

Watson et al..$^{5}$ summarized nearly 40 published intercomparison studies of optical, thermal, and photoacoustic measures of BC and EC. Some comparisons showed good agreement among the different methods, whereas others showed wide disagreements for the same methods applied to different samples. Agreement was typically better for laboratory-generated particles than for ambient air samples. Watson et al. ${ }^{5}$ concluded that citation of a single BC or EC comparison study is insufficient to justify comparability among the different measurement methods. Lacking a more systematic understanding of the differences, aerosol- and instrument-specific comparisons are needed to use measurements interchangeably.

For this study, eight continuous or semicontinuous and integrated BC or EC measurement methods, as detailed in Table 1, were used to sample air at the Fresno Supersite. ${ }^{27,28}$ In addition to these continuous and timeintegrated carbon measurements, the Supersite provides continuous data of 1 -hr or less for particle number concentration (3-407 nm), particle light scattering $\left(b_{\text {scat }}[530\right.$ $\mathrm{nm}]$, units of $\left.\mathrm{Mm}^{-1}\right)$, fine particulate matter $\left(\mathrm{PM}_{2.5}\right)$ mass, nitrate $\left(\mathrm{NO}_{3}{ }^{-}\right)$, and gaseous nitrogen oxides $\left(\mathrm{NO}_{\mathrm{x}}\right)$, carbon monoxide $(\mathrm{CO})$, and ozone $\left(\mathrm{O}_{3}\right)$ that can be used to better understand differences among these $\mathrm{BC}$ and $\mathrm{EC}$ measurements. The analysis approach taken here can be applied at other sites that use similar measurements.

\section{EXPERIMENTAL APPROACH}

Fresno is located in California's San Joaquin Valley (SJV), which is in nonattainment of the $\mathrm{PM}_{2.5}$ National Ambient Air Quality Standards. Air pollution in central California is affected by different types of emissions, including point sources (e.g., steam generators and natural gas combustion), area sources (e.g., residential wood combustion [RWC] and cooking), on-road and non-road mobile sources (e.g., gasoline- and diesel-fueled vehicles, high emitters, and cold starts in winter), agricultural sources (e.g., tillage, field burning, and fertilizers), and biogenic sources (e.g., plants and crops). ${ }^{27} \mathrm{OC}$ and EC are important components of $\mathrm{PM}_{2.5}$ in the SJV, 29,30 and the relative abundances of OC and EC are used to evaluate source contributions for emission reduction strategies. The 
Table 1. Summary of BC and EC measurement methods.

\begin{tabular}{|c|c|c|c|c|c|c|c|}
\hline Instruments ${ }^{\mathbf{a}}$ & $\begin{array}{l}\text { Observable } \\
\text { (units) }\end{array}$ & Measurement Principle ${ }^{b}$ & $\begin{array}{l}\text { Wavelength } \\
\quad(\mathrm{nm})\end{array}$ & Inlet & $\begin{array}{l}\text { Collection } \\
\text { Medium }\end{array}$ & $\begin{array}{l}\text { Flow } \\
\text { Rate } \\
\text { (L/min) }\end{array}$ & $\begin{array}{l}\text { Averaging } \\
\text { Time }\end{array}$ \\
\hline MAAP & $\begin{array}{l}b_{\text {abs }}\left(\mathrm{Mm}^{-1}\right) \\
\mathrm{BC}\left(\mu \mathrm{g} / \mathrm{m}^{3}\right)\end{array}$ & $\begin{array}{l}\text { Light reflected from the filter at } 130^{\circ} \\
\text { and } 165^{\circ} \text { from the illumination } \\
\text { direction are used in a radiative } \\
\text { transfer model to estimate } b_{\text {abs }} \\
\text { and is converted to } \mathrm{BC} \text { using } \sigma_{\text {abs }} \\
\text { of } 6.5 \mathrm{~m}^{2} / \mathrm{g} \text {. }\end{array}$ & 670 & $\mathrm{PM}_{2.5}$ cyclone & $\begin{array}{l}\text { Glass-fiber filter } \\
\text { tape }\end{array}$ & 16 & $1 \mathrm{~min}$ \\
\hline 2-AE & $\begin{array}{l}b_{\mathrm{abs}}\left(\mathrm{Mm}^{-1}\right) \\
\mathrm{BC}\left(\mu \mathrm{g} / \mathrm{m}^{3}\right)\end{array}$ & $\begin{array}{l}\text { Attenuation of light transmitted } \\
\text { through the filter tape is } \\
\text { measured and converted to BC }\end{array}$ & 370,880 & $\mathrm{PM}_{2.5}$ cyclone & $\begin{array}{l}\text { Quartz-fiber filter } \\
\text { tape }\end{array}$ & 6.8 & $5 \mathrm{~min}$ \\
\hline 7-AE & $\begin{array}{l}b_{\mathrm{abs}}\left(\mathrm{Mm}^{-1}\right) \\
\mathrm{BC}\left(\mu \mathrm{g} / \mathrm{m}^{3}\right)\end{array}$ & using $\sigma_{\text {abs }}$ of $14,625 / \lambda\left(\mathrm{m}^{2} / \mathrm{g}\right)$ & $\begin{array}{c}370,470,520,590 \\
660,880,950\end{array}$ & $\mathrm{PM}_{2.5}$ cyclone & $\begin{array}{l}\text { Quartz-fiber filter } \\
\text { tape }\end{array}$ & 6.8 & $5 \min$ \\
\hline \multirow[t]{2}{*}{ Sunset } & OC, EC $\left(\mu \mathrm{g} / \mathrm{m}^{3}\right)$ & $\begin{array}{l}\text { Particles collected on a quartz-fiber } \\
\text { filter are subjected to different } \\
\text { temperature ramps following the } \\
\mathrm{NIOSH} 5040 \mathrm{TOT} \text { protocol, and } \\
\text { the resulting } \mathrm{CO}_{2} \text { is analyzed by } \\
\text { NDIR. Pyrolysis correction is by } \\
\text { laser transmittance. }\end{array}$ & 660 & $\mathrm{PM}_{2.5}$ cyclone & $\begin{array}{l}\text { Quartz-fiber filter } \\
\text { tape }\end{array}$ & 8.5 & $1 \mathrm{hr}$ \\
\hline & $\mathrm{BC}\left(\mu \mathrm{g} / \mathrm{m}^{3}\right)$ & $\begin{array}{l}\text { Light transmitted through the filter is } \\
\text { monitored during the collection } \\
\text { phase to quantify } \mathrm{BC} \text {. }\end{array}$ & 660 & $\mathrm{PM}_{2.5}$ cyclone & $\begin{array}{l}\text { Quartz-fiber filter } \\
\text { tape }\end{array}$ & 8.5 & $1 \mathrm{hr}$ \\
\hline PAS-PAH & $\begin{array}{l}\text { Particle-bound PAH } \\
\text { (fA) }\end{array}$ & $\begin{array}{l}\text { The air stream is exposed to UV } \\
\text { radiation, which ionizes the } \\
\text { particle-bound PAH molecules. } \\
\text { The charged particles are } \\
\text { collected on a filter element, and } \\
\text { the pizeoelectric current is } \\
\text { proportional to the particle-bound } \\
\text { PAH. }\end{array}$ & 225 & $\mathrm{PM}_{2.5}$ impactor & $\begin{array}{l}\text { Filter element } \\
\text { mounted in a } \\
\text { Faraday cage }\end{array}$ & 2 & $5 \min$ \\
\hline $\begin{array}{l}\text { FRM filter samples } \\
\text { analyzed by } \\
\text { IMPROVE TOR }\end{array}$ & $\begin{array}{c}\text { OC, EC, and TC } \\
\left(\mu \mathrm{g} / \mathrm{m}^{3}\right)\end{array}$ & $\begin{array}{l}\text { Particles collected on a quartz-fiber } \\
\text { filter are subjected to different } \\
\text { temperature ramps following the } \\
\text { IMPROVE TOR protocol. The } \\
\text { resulting } \mathrm{CO}_{2} \text { is converted to } \mathrm{CH}_{4} \\
\text { and analyzed by FID. Pyrolysis } \\
\text { correction is by laser reflectance. }\end{array}$ & 632.8 & $\mathrm{PM}_{2.5}$ impactor & Quartz-fiber filter & 16.7 & $24 \mathrm{hr}$ \\
\hline
\end{tabular}

Notes: 'MAAP, model 5012, Thermo-Electron, Waltham, MA); 2-AE, model AE-21, Magee Scientific, Berkeley, CA); 7-AE, model AE-31, Magee Scientific, Berkeley, CA); photoacoustic, photoacoustic analyzer (DRI, Reno, NV); Sunset, semicontinuous Sunset Laboratory Carbon Aerosol Analysis Field Instrument (Sunset Laboratory, Tigard, OR) following the National Institute for Occupational Safety and Health (NIOSH) TOT 5040 protocol; R\&P 5400, ambient carbon particulate monitor (Rupprecht \& Patashnick, Albany, NY); PAS-PAH, particle-bound PAH monitor (model PAS2000, EcoChem Analytics, League City, TX); FRM, Federal Reference Monitor (Andersen Instruments, Smyrna, GA); ${ }^{\mathrm{b}} \mathrm{TSP}=$ total suspended particles; NA = not applicable; PAS = photoelectric aerosol sensor; FID = flame-ionization detector; ' IMPROVE TOR as in ref. 5.

Fresno Supersite (3425 First Street, Fresno, CA) is located near commercial buildings, restaurants, churches, schools, and residential areas and is $\sim 5.5 \mathrm{~km}$ northeast of the downtown Fresno commercial district. First Street is a four-lane artery with moderate traffic levels; sampling inlets are on the rooftop of a two-story building on the 
west side of the street. This analysis examines measurements from December 2003 through November 2004.

For the Magee Scientific dual-wavelength (2-AE) and seven-color (7-AE) aethalometers, ${ }^{31,32}$ particles are deposited on a quartz-fiber filter tape and the change of light transmission through the filter tape measured by light source and detector is used to calculate 5-min average BC concentrations. The filter tape is automatically advanced when its optical density attains 0.75 . The attenuation is converted to a BC mass concentration, using a $\sigma_{\text {abs }}$ of $14625 / \lambda\left(\mathrm{m}^{2} / \mathrm{g}\right)$. In normal operation, corrections are not made for filter loading, filter scattering, or aerosol scattering. ${ }^{8}$

For the Thermo multi-angle absorption photometer (MAAP), samples are deposited on a filter tape similar to the process in the aethalometer. ${ }^{10,33,34}$ The MAAP measures reflectance of $670 \mathrm{~nm}$ light at $130^{\circ}$ and $165^{\circ}$ from the projected light beam. Use of these as inputs to a two-stream-approximation radiative transfer model minimizes filter- and aerosol-scattering biases, returning a $b_{\text {abs }}(670 \mathrm{~nm})$ comparable to that of the photoacoustic analyzer for kerosene smoke and electric arc graphite. ${ }^{34}$ An empirical $\sigma_{\text {abs }}(670 \mathrm{~nm})$ of $6.5 \mathrm{~m}^{2} / \mathrm{g}$ was applied to convert 1 -min $b_{\text {abs }}$ to BC. Comparison of the MAAP samples with EC derived from the German extraction/thermal desorption method ${ }^{35}$ yielded $\sigma_{\text {abs }}(670 \mathrm{~nm})$ values of $6.4 \pm$ $1 \mathrm{~m}^{2} / \mathrm{g}$ for urban Berlin aerosol, $6.5 \pm 0.7 \mathrm{~m}^{2} / \mathrm{g}$ for urban Bad Korzingen aerosol, and $4.8 \pm 1.2 \mathrm{~m}^{2} / \mathrm{g}$ for non-urban Mount Kleiner Feldberg aerosol with EC $<0.5 \mu \mathrm{g} / \mathrm{m}^{3}$. The VDI method reports higher fractions of EC than many other methods, ${ }^{36}$ including the Interagency Monitoring of Protected Visual Environments (IMPROVE) thermal/ optical reflectance (TOR) protocol ${ }^{17,37,38}$ applied to $\mathrm{PM}_{2.5}$ filter samples at the Fresno Supersite.

The Desert Research Institute (DRI) photoacoustic analyzer measures 5-min average $b_{\text {abs }}(1047 \mathrm{~nm}) .^{20,39,40} \mathrm{An}$ empirical $\sigma_{\text {abs }}(1047 \mathrm{~nm})$ of $5 \mathrm{~m}^{2} / \mathrm{g}$ was applied to convert photoacoustic $b_{\text {abs }}(1047 \mathrm{~nm})$ to BC, based on comparison samples from IMPROVE EC and photoacoustic BC measurements of diesel emissions. ${ }^{40}$

The Sunset analyzer, ${ }^{41,42}$ which is based on thermal/ optical transmittance (TOT), draws air through a quartzfiber filter for $45 \mathrm{~min}$ at $8.5 \mathrm{~L} / \mathrm{min}$ to obtain the sample. The sampling port is then sealed for $15 \mathrm{~min}$, and the sample is heated to $250,500,650$, and $850{ }^{\circ} \mathrm{C}$ in $100 \% \mathrm{He}$, then to $650,750,850$, and $940{ }^{\circ} \mathrm{C}$ in $98 \% \mathrm{He} / 2 \%$ oxygen $\left(\mathrm{O}_{2}\right)$ that backflows through the filter. The evolved carbon is oxidized to carbon dioxide $\left(\mathrm{CO}_{2}\right)$, then quantified by a nondispersive IR (NDIR) detector. Charred OC is monitored by transmittance at $\lambda=660 \mathrm{~nm}$. The carbon that evolves after the transmittance achieves its original value is classified as EC. The filter is presumably free of carbon after the analysis. The sampling inlet is opened, and the cycle begins again for the next hour. This unit also monitors the transmitted laser signal during the collection phase to obtain a $\mathrm{BC}$ measurement by the same principle as applied in the aethalometer.

For the R\&P 5400 carbon monitor, ${ }^{43}$ particles are drawn through a $\mathrm{PM}_{2.5}$ inlet, deposited on an impactor, and heated by a Xenon lamp to $275^{\circ} \mathrm{C}$ in air, combusted to $\mathrm{CO}_{2}$, and measured with an NDIR to determine 1-hr average OC. The temperature is increased to $750{ }^{\circ} \mathrm{C}$ to measure total carbon (TC). EC is determined based on the difference between TC and OC.

The EcoChem particle-bound polycyclic aromatic hydrocarbon (PAH) monitor ${ }^{44}$ uses a photoelectric sensor with an excimer lamp that produces UV radiation (225 $\mathrm{nm})$ to photo-ionize the sampled particles. This photon energy minimizes ionization of gas molecules. The charged particles are collected on a filter element mounted in a Faraday cage, and the electric current is measured with an electrometer. The photoelectric current is proportional to the concentration of particle-bound PAHs, weighted according to an average ionization response. This is a relative measure of particle-bound $\mathrm{PAH}$; therefore, the results are reported in terms of the electrometer output in femptoamps (fA).

These continuous BC measurements are compared with each other and with EC determined by IMPROVETOR analysis $17,37,38$ of 24-hr quartz-fiber filters from a $\mathrm{PM}_{2.5}$ Federal Reference Monitor (FRM) ${ }^{45}$ operated every sixth day. Filters were baked at $900{ }^{\circ} \mathrm{C}$ for $4 \mathrm{hr}$ before sampling to remove adsorbed organic vapors. ${ }^{46}$ For IMPROVE_TOR analysis, the sample is heated in successive steps of $120^{\circ} \mathrm{C}$ (OC1), $250{ }^{\circ} \mathrm{C}$ (OC2), $450{ }^{\circ} \mathrm{C}$ (OC3), and $550{ }^{\circ} \mathrm{C}(\mathrm{OC} 4)$ in $\mathrm{He}$ and $550{ }^{\circ} \mathrm{C}(\mathrm{EC} 1), 700{ }^{\circ} \mathrm{C}(\mathrm{EC} 2)$, and $800{ }^{\circ} \mathrm{C}(\mathrm{EC} 3)$ in $98 \% \mathrm{He} / 2 \% \mathrm{O}_{2}$. Evolved carbon is oxidized to $\mathrm{CO}_{2}$ and then reduced to methane $\left(\mathrm{CH}_{4}\right)$ for detection by a flame-ionization detector (FID). The pyrolyzed (i.e., charred) OC is monitored by reflectance at $\lambda=632.8$ nm. Until the laser signal returns to its initial value, the portion of EC1 is assigned to pyrolyzed OC (OP). The OC is defined by the sum of OC1, OC2, OC3, OC4, and OP, whereas the EC is defined by EC1 + EC2 + EC3 - OP.

Other continuous measurements examined in this analysis include (1) ultrafine and fine particle numbers from nano (3-84 $\mathrm{nm}$ ) and standard (84-407 nm) scanning mobility particle sizers (SMPS; models 3936N25A and 3936L10, TSI, Shoreview, MN); ${ }^{5,47}$ (2) $b_{\text {scat }}(530 \mathrm{~nm})$ by nephelometer (Radiance Research M903, Seattle, WA); 48 (3) $\mathrm{PM}_{2.5}$ mass concentration by tapered element oscillating microbalance (TEOM; model 1400a, Rupprecht and Patashnick, Albany, NY);49 (4) $\mathrm{NO}_{3}{ }^{-}$by flash volatilization (model R\&P 8400N, Rupprecht and Patashnick, Albany, NY); 50 (5) $\mathrm{NO}_{\mathrm{x}}$ by chemiluminescence (model TEI 42, Thermo Electron Inc., Franklin, MA); (6) CO by IR gas filter correlation (model DASIBI 3008, Environmental Corp., Glendale, CA); (7) $\mathrm{O}_{3}$ by UV absorption (model API 400, API Inc., San Diego, CA); and (8) meteorology measurements (i.e., wind speed and direction [model 05305L high-sensitivity wind vane and anemometer, Met One, Grants Pass, OR], temperature [model CS500L platinum resistance sensor, Met One], relative humidity [RH; model CS capacitance sensor, Met One], solar radiation [model LI200X-L pyranometer, Li-Cor, Lincoln, NE], and atmospheric pressure [model Met One piezofilm sensor, Met One]).

\section{RESULTS}

Comparison of BC and EC Measurements

Table 2 lists comparability statistics, obtained with the assumed $\sigma_{\mathrm{abs}}(\lambda)$, for the different BC and EC measurements. These statistics reflect the differences evident in 
Table 2. Comparison statistics for collocated BC and EC measurements between December 1, 2003, and November 30, 2004

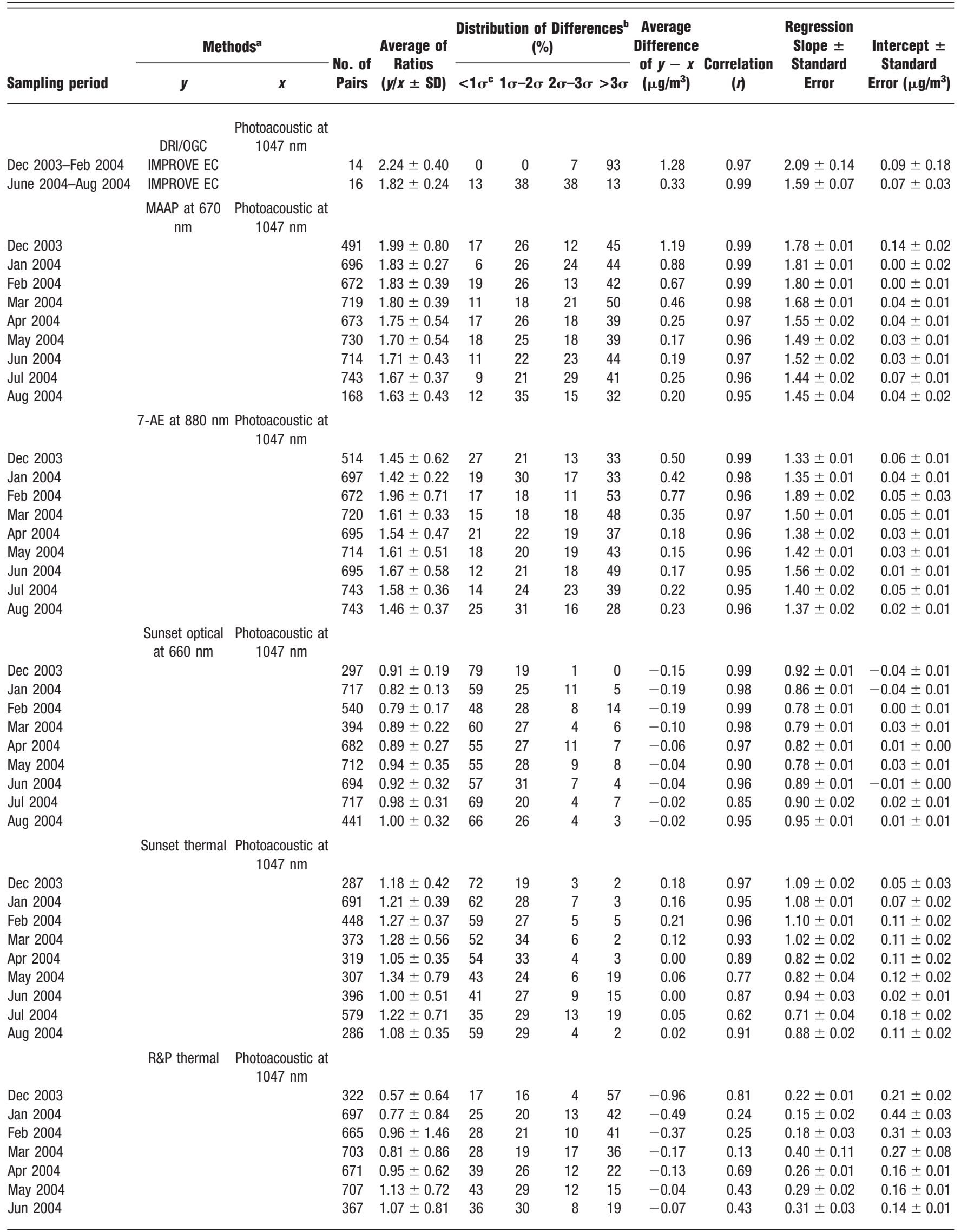


Table 2. Cont.

\begin{tabular}{|c|c|c|c|c|c|c|c|c|c|c|c|c|}
\hline \multirow[b]{2}{*}{ Sampling period } & \multicolumn{2}{|c|}{ Methods $^{a}$} & \multirow{2}{*}{$\begin{array}{l}\text { No. of } \\
\text { Pairs }\end{array}$} & \multirow{2}{*}{$\begin{array}{c}\text { Average of } \\
\text { Ratios } \\
\text { (y/x } \pm \text { SD) }\end{array}$} & \multicolumn{4}{|c|}{$\begin{array}{c}\text { Distribution of Differences } \\
(\%)\end{array}$} & \multirow{2}{*}{$\begin{array}{c}\text { Average } \\
\text { Difference } \\
\text { of } y-x \\
\left(\mu \mathrm{g} / \mathrm{m}^{3}\right)\end{array}$} & \multirow{2}{*}{$\begin{array}{c}\text { Correlation } \\
\text { (I) }\end{array}$} & \multirow{2}{*}{$\begin{array}{c}\text { Regression } \\
\text { Slope } \pm \\
\text { Standard } \\
\text { Error }\end{array}$} & \multirow{2}{*}{$\begin{array}{c}\text { Intercept } \pm \\
\text { Standard } \\
\text { Error }\left(\mu \mathrm{g} / \mathrm{m}^{3}\right)\end{array}$} \\
\hline & $y$ & $x$ & & & $<1 \sigma^{\mathrm{c}}$ & $1 \sigma-2 \sigma$ & $2 \sigma-3 \sigma$ & $>3 \sigma$ & & & & \\
\hline & РАН & $\begin{array}{c}\text { Photoacoustic at } \\
1047 \mathrm{~nm}\end{array}$ & & & & & & & & & & \\
\hline Dec 2003 & & & 323 & NA NA & NA & NA & NA & NA & NA & 0.91 & $11.42 \pm 0.29$ & $1.34 \pm 0.51$ \\
\hline Mar 2004 & & & 720 & NA NA & NA & NA & NA & NA & NA & 0.81 & $8.64 \pm 0.24$ & $-1.36 \pm 0.17$ \\
\hline Apr 2004 & & & 683 & NA NA & NA & NA & NA & NA & NA & 0.76 & $5.25 \pm 0.17$ & $-0.07 \pm 0.08$ \\
\hline May 2004 & & & 706 & NA NA & NA & NA & NA & NA & NA & 0.77 & $4.54 \pm 0.14$ & $0.22 \pm 0.05$ \\
\hline Jun 2004 & & & 695 & NA NA & NA & NA & NA & NA & NA & 0.78 & $3.52 \pm 0.11$ & $0.30 \pm 0.04$ \\
\hline Jul 2004 & & & 720 & NA NA & NA & NA & NA & NA & NA & 0.70 & $4.06 \pm 0.16$ & $-0.07 \pm 0.08$ \\
\hline Aug 2004 & & & 720 & NA NA & NA & NA & NA & NA & NA & 0.73 & $4.56 \pm 0.16$ & $-0.41 \pm 0.11$ \\
\hline Feb 2004 & & & 672 & $1.04 \pm 0.11$ & 89 & 8 & 3 & 1 & 0.01 & 0.99 & $0.96 \pm 0.00$ & $0.05 \pm 0.01$ \\
\hline Mar 2004 & & & 720 & $1.04 \pm 0.09$ & 94 & 5 & 1 & 0 & 0.02 & 0.99 & $0.99 \pm 0.01$ & $0.03 \pm 0.01$ \\
\hline Apr 2004 & & & 527 & $1.04 \pm 0.21$ & 88 & 8 & 2 & 1 & 0.01 & 0.98 & $1.01 \pm 0.01$ & $0.01 \pm 0.01$ \\
\hline May 2004 & & & 252 & $1.09 \pm 0.11$ & 83 & 13 & 1 & 2 & 0.03 & 0.99 & $1.09 \pm 0.01$ & $0.00 \pm 0.00$ \\
\hline Jun 2004 & & & 696 & $1.07 \pm 0.10$ & 86 & 10 & 3 & 1 & 0.03 & 0.98 & $1.00 \pm 0.01$ & $0.03 \pm 0.00$ \\
\hline Jul 2004 & & & 744 & $1.09 \pm 0.11$ & 81 & 15 & 2 & 1 & 0.05 & 0.98 & $1.05 \pm 0.01$ & $0.02 \pm 0.01$ \\
\hline Aug 2004 & & & 744 & $1.09 \pm 0.10$ & 84 & 11 & 3 & 2 & 0.07 & 0.99 & $1.08 \pm 0.01$ & $0.01 \pm 0.01$ \\
\hline Sep 2004 & & & 702 & $1.07 \pm 0.12$ & 82 & 14 & 3 & 1 & 0.05 & 0.98 & $1.01 \pm 0.01$ & $0.04 \pm 0.01$ \\
\hline Oct 2004 & & & 629 & $1.14 \pm 0.19$ & 73 & 18 & 7 & 2 & 0.13 & 0.99 & $1.03 \pm 0.01$ & $0.09 \pm 0.01$ \\
\hline \multirow[t]{2}{*}{ Nov 2004} & & & 660 & $1.12 \pm 0.13$ & 77 & 16 & 4 & 3 & 0.20 & 0.99 & $1.08 \pm 0.01$ & $0.05 \pm 0.01$ \\
\hline & $2-\mathrm{AE}$ at $370 \mathrm{~nm}$ & $7-\mathrm{AE}$ at $370 \mathrm{~nm}$ & & & & & & & & & & \\
\hline Dec 2003 & & & 719 & $1.16 \pm 0.26$ & 71 & 18 & 6 & 4 & 0.22 & 0.99 & $1.06 \pm 0.01$ & $0.09 \pm 0.02$ \\
\hline Sep 2004 & & & 702 & $1.12 \pm 0.17$ & 64 & 22 & 9 & 5 & 0.08 & 0.97 & $1.02 \pm 0.01$ & $0.06 \pm 0.01$ \\
\hline Oct 2004 & & & 629 & $1.18 \pm 0.23$ & 62 & 22 & 10 & 6 & 0.16 & 0.98 & $1.05 \pm 0.01$ & $0.10 \pm 0.01$ \\
\hline \multirow[t]{2}{*}{ Nov 2004} & & & 660 & $1.17 \pm 0.20$ & 64 & 22 & 8 & 5 & 0.29 & 0.99 & $1.11 \pm 0.01$ & $0.06 \pm 0.02$ \\
\hline & PAH & $7-\mathrm{AE}$ at $370 \mathrm{~nm}$ & & & & & & & & & & \\
\hline Dec 2003 & & & 543 & NA NA & NA & NA & NA & NA & NA & 0.91 & $7.03 \pm 0.14$ & $-0.41 \pm 0.40$ \\
\hline Jan 2004 & & & NA & NA NA & NA & NA & NA & NA & NA & NA & $N A \pm N A$ & $N A \pm N A$ \\
\hline Feb 2004 & & & 632 & NA NA & NA & NA & NA & NA & NA & 0.92 & $4.70 \pm 0.08$ & $-0.40 \pm 0.17$ \\
\hline Mar 2004 & & & 720 & NA NA & NA & NA & NA & NA & NA & 0.84 & $5.62 \pm 0.13$ & $-1.44 \pm 0.15$ \\
\hline Apr 2004 & & & 696 & NA NA & NA & NA & NA & NA & NA & 0.74 & $3.71 \pm 0.13$ & $-0.16 \pm 0.09$ \\
\hline May 2004 & & & 719 & NA NA & NA & NA & NA & NA & NA & 0.71 & $2.80 \pm 0.11$ & $0.33 \pm 0.06$ \\
\hline Jun 2004 & & & 696 & NA NA & NA & NA & NA & NA & NA & 0.79 & $2.50 \pm 0.07$ & $0.25 \pm 0.04$ \\
\hline Jul 2004 & & & 719 & NA NA & NA & NA & NA & NA & NA & 0.73 & $3.17 \pm 0.11$ & $-0.24 \pm 0.07$ \\
\hline \multirow[t]{2}{*}{ Aug 2004} & & & 719 & NA NA & NA & NA & NA & NA & NA & 0.71 & $3.59 \pm 0.13$ & $-0.45 \pm 0.12$ \\
\hline & $\mathrm{DRI} / \mathrm{OGC}$ & $\begin{array}{c}\text { MAAP at } 670 \\
n m\end{array}$ & & & & & & & & & & \\
\hline Dec 2003-Feb 2004 & IMPROVE EC & MAAP & 13 & $1.18 \pm 0.18$ & 31 & 23 & 23 & 23 & 0.98 & 0.33 & $1.16 \pm 0.07$ & $0.01 \pm 0.16$ \\
\hline \multirow[t]{2}{*}{ June 2004-Aug 2004} & IMPROVE EC & MAAP & 12 & $1.12 \pm 0.13$ & 67 & 25 & 8 & 0 & 0.98 & 0.05 & $0.94 \pm 0.06$ & $0.09 \pm 0.03$ \\
\hline & DRI/OGC & $7-\mathrm{AE}$ at $880 \mathrm{~nm}$ & & & & & & & & & & \\
\hline Dec 2003-Feb 2004 & IMPROVE EC & $7-A E$ & 15 & $1.64 \pm 0.32$ & 7 & 7 & 33 & 53 & 0.95 & 0.88 & $1.49 \pm 0.14$ & $0.13 \pm 0.24$ \\
\hline June 2004-Aug 2004 & IMPROVE EC & $7-\mathrm{AE}$ & 16 & $1.23 \pm 0.2$ & 69 & 25 & 6 & 0 & 0.97 & 0.12 & $1.08 \pm 0.07$ & $0.06 \pm 0.05$ \\
\hline & $\begin{array}{c}\text { Photoacoustic at } \\
1047 \mathrm{~nm}\end{array}$ & $\begin{array}{c}\text { MAAP at } 670 \\
\mathrm{~nm}\end{array}$ & & & & & & & & & & \\
\hline Dec 2003 & & & 491 & $0.53 \pm 0.09$ & 17 & 26 & 12 & 45 & 0.99 & -1.19 & $0.55 \pm 0.00$ & $-0.05 \pm 0.01$ \\
\hline
\end{tabular}


Table 2. Cont.

\begin{tabular}{|c|c|c|c|c|c|c|c|c|c|c|c|c|}
\hline \multirow[b]{2}{*}{ Sampling period } & \multicolumn{2}{|c|}{ Methods $^{a}$} & \multirow{2}{*}{$\begin{array}{l}\text { No. of } \\
\text { Pairs }\end{array}$} & \multirow{2}{*}{$\begin{array}{c}\text { Average of } \\
\text { Ratios } \\
(y / x \pm S D)\end{array}$} & \multicolumn{4}{|c|}{$\begin{array}{c}\text { Distribution of Differences } \\
(\%)\end{array}$} & \multirow{2}{*}{$\begin{array}{c}\text { Average } \\
\text { Difference } \\
\text { of } y-x \\
\left(\mu \mathrm{g} / \mathrm{m}^{3}\right)\end{array}$} & \multirow{2}{*}{$\begin{array}{c}\text { Correlation } \\
\text { (I) }\end{array}$} & \multirow{2}{*}{$\begin{array}{l}\text { Regression } \\
\text { Slope } \pm \\
\text { Standard } \\
\text { Error }\end{array}$} & \multirow{2}{*}{$\begin{array}{c}\text { Intercept } \pm \\
\text { Standard } \\
\text { Error }\left(\mu \mathrm{g} / \mathrm{m}^{3}\right)\end{array}$} \\
\hline & $y$ & $x$ & & & $<1 \sigma^{\mathrm{c}}$ & $1 \sigma-2 \sigma$ & $2 \sigma-3 \sigma$ & $>\mathbf{3 \sigma}$ & & & & \\
\hline Feb 2004 & & & 672 & $0.57 \pm 0.17$ & 19 & 26 & 13 & 42 & 0.99 & -0.67 & $0.54 \pm 0.00$ & $0.01 \pm 0.01$ \\
\hline Mar 2004 & & & 719 & $0.57 \pm 0.10$ & 11 & 18 & 21 & 50 & 0.98 & -0.46 & $0.57 \pm 0.00$ & $0.00 \pm 0.00$ \\
\hline Apr 2004 & & & 673 & $0.62 \pm 0.17$ & 17 & 26 & 18 & 39 & 0.97 & -0.25 & $0.60 \pm 0.01$ & $0.01 \pm 0.01$ \\
\hline Jul 2004 & & & 743 & $0.62 \pm 0.12$ & 9 & 21 & 29 & 41 & 0.96 & -0.25 & $0.64 \pm 0.01$ & $-0.01 \pm 0.01$ \\
\hline \multirow[t]{2}{*}{ Aug 2004} & & & 168 & $0.65 \pm 0.15$ & 12 & 35 & 15 & 32 & 0.95 & -0.20 & $0.63 \pm 0.02$ & $0.01 \pm 0.01$ \\
\hline & $7-\mathrm{AE}$ at $880 \mathrm{~nm}$ & $\begin{array}{c}\text { MAAP at } 670 \\
n m\end{array}$ & & & & & & & & & & \\
\hline Dec 2003 & & & 645 & $0.75 \pm 0.08$ & 46 & 24 & 11 & 19 & 0.99 & -0.63 & $0.72 \pm 0.00$ & $0.04 \pm 0.01$ \\
\hline May 2004 & & & 720 & $0.96 \pm 0.14$ & 85 & 10 & 3 & 2 & 0.98 & -0.02 & $0.91 \pm 0.01$ & $0.02 \pm 0.00$ \\
\hline Jun 2004 & & & 695 & $0.96 \pm 0.12$ & 87 & 11 & 1 & 1 & 0.98 & 0.02 & $1.02 \pm 0.01$ & $-0.03 \pm 0.00$ \\
\hline Jul 2004 & & & 743 & $0.95 \pm 0.14$ & 83 & 14 & 3 & 1 & 0.97 & -0.03 & $0.95 \pm 0.01$ & $0.00 \pm 0.01$ \\
\hline \multirow[t]{2}{*}{ Aug 2004} & & & 168 & $0.92 \pm 0.08$ & 84 & 10 & 4 & 3 & 0.99 & -0.05 & $0.86 \pm 0.01$ & $0.02 \pm 0.01$ \\
\hline & $7-\mathrm{AE}$ at $660 \mathrm{~nm}$ & $\begin{array}{c}\text { MAAP at } 670 \\
n m\end{array}$ & & & & & & & & & & \\
\hline Dec 2003 & & & 645 & $0.79 \pm 0.08$ & 52 & 23 & 10 & 15 & 0.99 & -0.53 & $0.76 \pm 0.00$ & $0.04 \pm 0.01$ \\
\hline Jan 2004 & & & 720 & $0.81 \pm 0.08$ & 51 & 31 & 12 & 7 & 0.99 & -0.36 & $0.80 \pm 0.00$ & $0.02 \pm 0.01$ \\
\hline Feb 2004 & & & 672 & $0.89 \pm 0.11$ & 69 & 19 & 6 & 6 & 0.99 & -0.20 & $0.85 \pm 0.00$ & $0.03 \pm 0.01$ \\
\hline Mar 2004 & & & 720 & $0.94 \pm 0.09$ & 92 & 6 & 1 & 0 & 0.98 & -0.06 & $0.92 \pm 0.01$ & $0.02 \pm 0.01$ \\
\hline Apr 2004 & & & 696 & $0.94 \pm 0.11$ & 83 & 13 & 3 & 1 & 0.99 & -0.04 & $0.92 \pm 0.01$ & $0.01 \pm 0.00$ \\
\hline May 2004 & & & 720 & $1.00 \pm 0.13$ & 86 & 9 & 3 & 2 & 0.98 & 0.00 & $0.93 \pm 0.01$ & $0.03 \pm 0.00$ \\
\hline Mar 2004 & & & 397 & $0.48 \pm 0.06$ & 6 & 22 & 25 & 48 & 0.98 & -0.62 & $0.47 \pm 0.01$ & $0.01 \pm 0.02$ \\
\hline Apr 2004 & & & 361 & $0.51 \pm 0.07$ & 6 & 23 & 27 & 44 & 0.96 & -0.45 & $0.53 \pm 0.01$ & $-0.02 \pm 0.01$ \\
\hline May 2004 & & & 711 & $0.55 \pm 0.07$ & 8 & 37 & 22 & 33 & 0.97 & -0.28 & $0.57 \pm 0.01$ & $-0.01 \pm 0.01$ \\
\hline Jun 2004 & & & 694 & $0.51 \pm 0.07$ & 1 & 19 & 43 & 38 & 0.98 & -0.31 & $0.61 \pm 0.01$ & $-0.05 \pm 0.00$ \\
\hline Jul 2004 & & & 716 & $0.59 \pm 0.10$ & 5 & 42 & 32 & 21 & 0.95 & -0.26 & $0.69 \pm 0.01$ & $-0.05 \pm 0.01$ \\
\hline \multirow[t]{2}{*}{ Aug 2004} & & & 167 & $0.75 \pm 0.17$ & 51 & 28 & 12 & 9 & 0.90 & -0.15 & $0.72 \pm 0.03$ & $0.01 \pm 0.02$ \\
\hline & Sunset thermal & $\begin{array}{c}\text { MAAP at } 670 \\
n m\end{array}$ & & & & & & & & & & \\
\hline Dec 2003 & & & 559 & $0.63 \pm 0.20$ & 33 & 22 & 16 & 28 & 0.98 & -1.05 & $0.59 \pm 0.01$ & $0.03 \pm 0.02$ \\
\hline Jan 2004 & & & 691 & $0.65 \pm 0.17$ & 27 & 32 & 16 & 25 & 0.96 & -0.74 & $0.60 \pm 0.01$ & $0.05 \pm 0.02$ \\
\hline Feb 2004 & & & 448 & $0.67 \pm 0.19$ & 32 & 29 & 19 & 20 & 0.98 & -0.67 & $0.61 \pm 0.01$ & $0.08 \pm 0.02$ \\
\hline Mar 2004 & & & 373 & $0.69 \pm 0.22$ & 31 & 29 & 19 & 21 & 0.94 & -0.40 & $0.61 \pm 0.01$ & $0.01 \pm 0.01$ \\
\hline Apr 2004 & & & 319 & $0.58 \pm 0.25$ & 17 & 31 & 20 & 32 & 0.88 & -0.38 & $0.56 \pm 0.02$ & $0.03 \pm 0.02$ \\
\hline May 2004 & & & 331 & $0.68 \pm 0.39$ & 26 & 36 & 16 & 22 & 0.88 & -0.19 & $0.89 \pm 0.03$ & $-0.12 \pm 0.02$ \\
\hline Jun 2004 & & & 369 & $0.63 \pm 0.26$ & 20 & 27 & 25 & 28 & 0.88 & -0.25 & $0.59 \pm 0.02$ & $0.02 \pm 0.01$ \\
\hline Jul 2004 & & & 572 & $0.73 \pm 0.39$ & 30 & 30 & 19 & 21 & 0.70 & -0.23 & $0.54 \pm 0.02$ & $0.11 \pm 0.02$ \\
\hline Aug 2004 & & & 94 & $0.73 \pm 0.37$ & 33 & 27 & 22 & 18 & 0.77 & -0.20 & $0.58 \pm 0.05$ & $0.09 \pm 0.04$ \\
\hline
\end{tabular}

Notes: ${ }^{\text {7 }}$-AE (in $\mu \mathrm{g} / \mathrm{m}^{3}$ ) at 370,660 , or $880 \mathrm{~nm}, 7-\mathrm{AE} \mathrm{BC}$ (in $\mu \mathrm{g} / \mathrm{m}^{3}$ ) at $\lambda=370,660,880 \mathrm{~nm}$, respectively; MAAP BC (in $\mu \mathrm{g} / \mathrm{m}^{3}$ ), at $\lambda=670 \mathrm{~nm}$; R\&P thermal, EC (in $\mu \mathrm{g} / \mathrm{m}^{3}$ ) thermally determined by R\&P 5400 ambient carbon particulate monitor; IMPROVE EC (in $\mu \mathrm{g} / \mathrm{m}^{3}$ ), measured by the DRI/OGC TOR carbon analyzer following the IMPROVE protocol; Sunset optical, EC (in $\left.\mu \mathrm{g} / \mathrm{m}^{3}\right)$ optically determined $(\lambda=660 \mathrm{~nm}$ ) with the Sunset Laboratory carbon analyzer; Sunset thermal, EC (in $\mu \mathrm{g} / \mathrm{m}^{3}$ ) determined by Sunset Laboratory carbon analyzer following the NIOSH 5040 protocol; PAH, particle-bound PAHs (in fA) measured by photoelectric aerosol sensor monitor; ${ }^{b}$ Fraction of pairs in percent with which the difference $(y-x)$ is less than or greater than one, two, or three times propagated measurement uncertainty (note that the precision interval, $\sigma$, is different from the mass absorption efficiency, $\sigma_{\text {abs }}$ ); ${ }^{c}$ Measurement uncertainty of $(y-x$ ). 


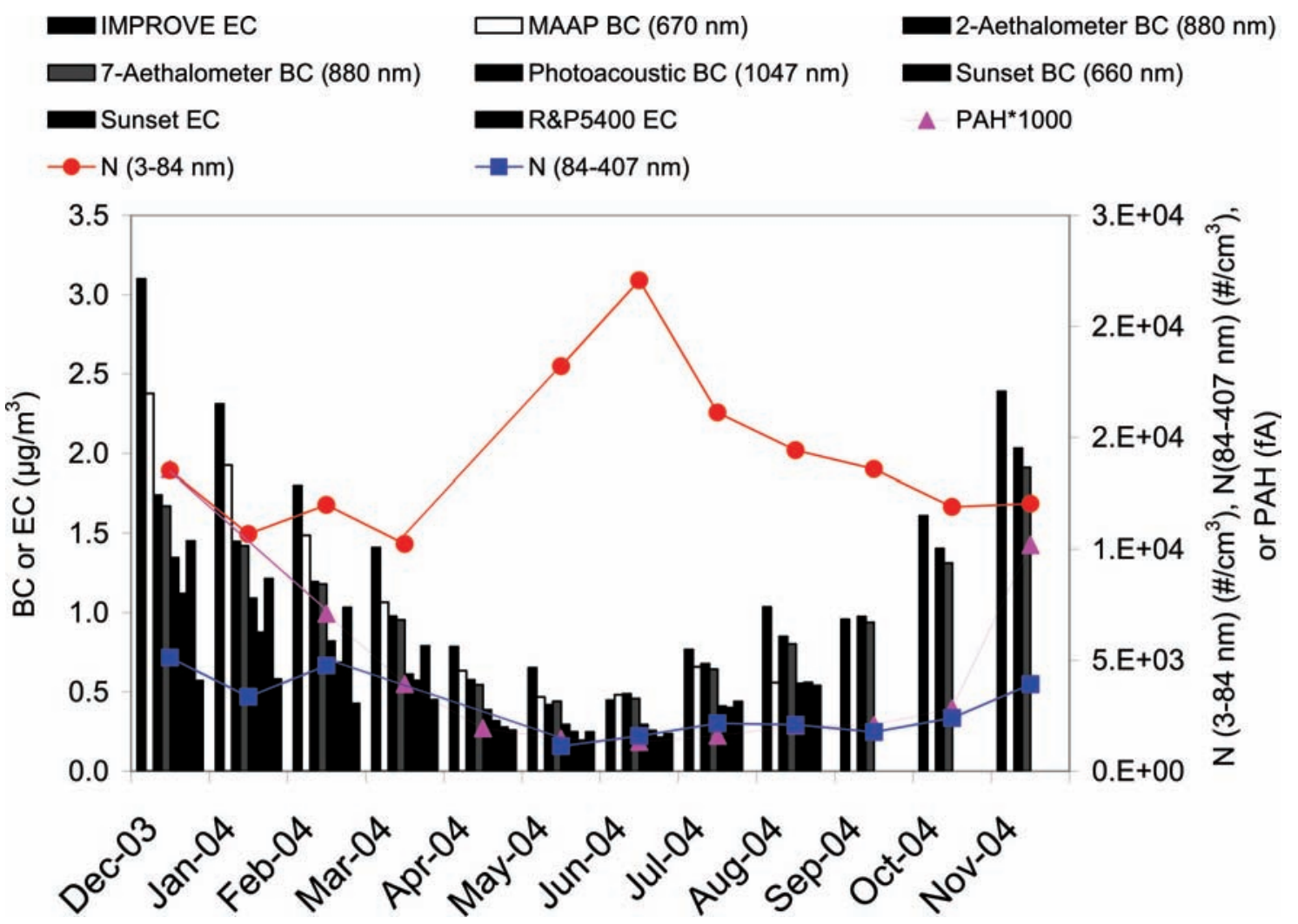

Figure 1. Monthly averages of $\mathrm{BC}$ or $\mathrm{EC}$ concentrations measured by eight carbon methods, particle-bound $\mathrm{PAH}$, and particle number concentrations in two size ranges (3-84 nm and $84-407 \mathrm{~nm}$ ) for ambient samples at the Fresno Supersite from December 2003 to November 2004.

Figure 1 . The average of $y / x$ with its standard deviation, the distribution of the difference $(y-x)$ between data pairs where $\sigma$ is the measurement uncertainty (i.e., the square root of the sum of squared uncertainties), the average of the differences $(\overline{y-x})$, the linear correlation coefficient $(r)$, and the regression slopes and intercepts with standard errors are calculated for each comparison. ${ }^{28}$

Data-pair requirements for carbon equivalence are met when the regression slope is $1 \pm 0.05$, the regression intercept is $0 \pm 1 \mu \mathrm{g} / \mathrm{m}^{3}(r>0.97)$, and the collocated precision is $2 \mu \mathrm{g} / \mathrm{m}^{3}$ or $5 \%$ (whichever is larger). ${ }^{28} \mathrm{Com}$ parability is attained when the regression slope equals unity within three standard errors, the regression intercept does not differ from zero by more than three standard errors, and $r$ is $>0.9$. Predictability is attained when $r$ is $>0.9$, but the slope and intercept exceeded those required for comparability. The equivalence criteria were established for $\mathrm{PM}_{2.5}$ mass comparison by the U.S. Environmental Protection Agency and are too stringent for the comparison of $\mathrm{PM}_{2.5}$ components.

As shown in Table 2 , the average difference $(\overline{y-x})$ was typically $<0.5 \mu \mathrm{g} / \mathrm{m}^{3}$ with a few exceptions, and in no case did the $\overline{y-x}$ exceed $1.4 \mu \mathrm{g} / \mathrm{m}^{3}$ of BC. The collocated 7-AE BC and 2-AE BC results met the equivalence criteria except during the months of May, August, and November 2004, when slopes were within $\sim 10 \%$ of unity; hereafter, the 7 -AE $\mathrm{BC}$ results are used to represent aethalometer BC. The filter-based IMPROVE EC results are highly correlated with the photoacoustic BC results $(0.97<r<0.99)$, but the IMPROVE EC slope indicates a 1.5 to 2 times higher concentration than the photoacoustic analyzer, using the $\sigma_{\text {abs }}(1047)=5 \mathrm{~m}^{2} / \mathrm{g}$ conversion. Compared with the photoacoustic $\mathrm{BC}$ results, the MAAP BC, 7-AE BC, Sunset optical (BC), Sunset thermal EC, and PAH values in winter also show high correlations $(r>0.9)$, but the slopes and average ratios differ from unity. The intercepts for these comparisons are well within $1 \mu \mathrm{g} / \mathrm{m}^{3}$, but the slopes vary from unity within a factor of 2 . Photoacoustic BC was much lower than either aethalometer or MAAP BC, as evidenced by the high slopes (1.3-2).

Sunset thermal EC results correlate better with the photoacoustic BC results in winter (December 2003 to February 2004; $0.95<r<0.97$ ) than in summer (June to August 2004; $0.62<r<0.91$ ), with slopes indicating a Sunset EC $\sim 10 \%$ higher than the photoacoustic BC in winter and 5-30\% lower than photoacoustic BC in summer. Compared with photoacoustic BC, the distribution of differences shows that $\sim 80 \%$ of the Sunset thermal and $\sim 85 \%$ of Sunset optical BC values are within \pm 3 precision intervals. Particle-bound PAH levels show higher correlations with photoacoustic BC for winter $(0.91<r<0.95)$ than for summer $(0.70<r<0.78)$. The R\&P $5400 \mathrm{EC}$ is not well correlated with the photoacoustic BC except for December $2003(r=0.81)$.

When the MAAP $(\lambda=670 \mathrm{~nm}) \mathrm{BC}$ or $7-\mathrm{AE}$ value is used as the benchmark, IMPROVE EC meets the requirements for comparability. The IMPROVE EC versus MAAP BC comparison almost meets the equivalence criteria in summer except for a lower slope $(0.94 \pm 0.06)$. The MAAP 
Table 3. Comparisons of carbon measurement methods with overall averages of BC or EC for collocated periods between December 1, 2003, and November 30, 2004, at the Fresno Supersite.

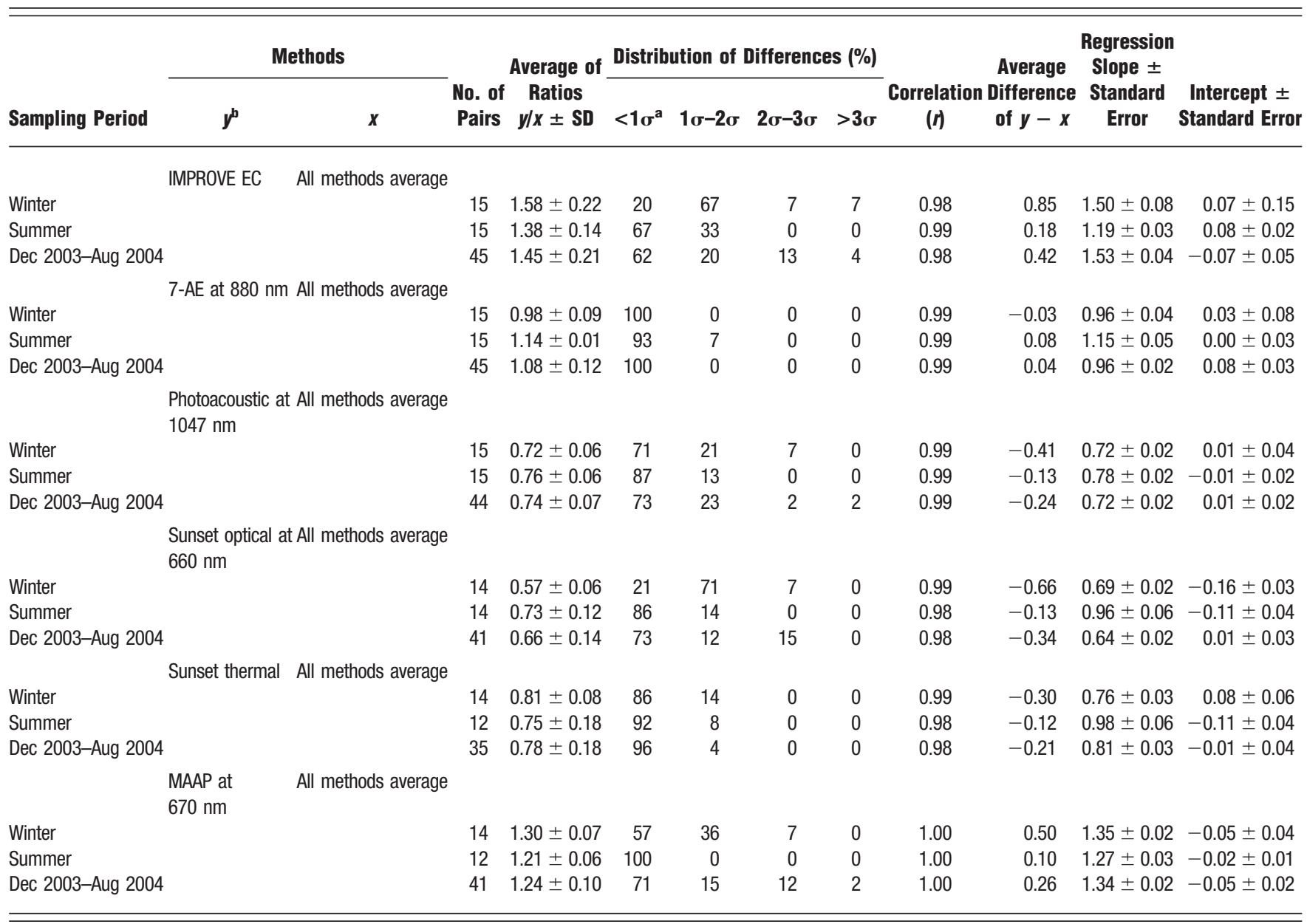

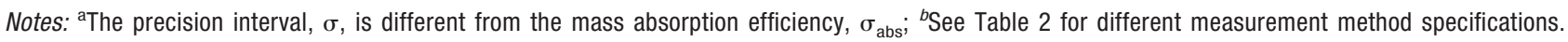

BC values are typically $30-50 \%$ higher than the photoacoustic and Sunset BC values, with small intercepts $\left(<0.1 \pm 0.02 \mu \mathrm{g} / \mathrm{m}^{3}\right)$. The best comparison is found for 7 -AE values at $\lambda=660$ or $880 \mathrm{~nm}$ and MAAP BC values, for which $>70 \%$ of the samples are within \pm 2 precision intervals and $>80 \%$ of the samples are within \pm 3 precision intervals.

Table 3 compares values from each instrument with the overall averages of all measurements, weighted by the number of available data points. BC or EC values from each method correlate well with the average $(r \geq 0.98)$, but regression slopes range from 0.64 (Sunset optical BC) to 1.53 (IMPROVE EC). For the overall averages, Sunset optical BC and Sunset thermal EC meet the comparability criteria during summer, whereas 7-AE BC meets the criteria in both winter and summer seasons. Deviations from unity are $10-20 \%$ higher for winter (from $-31 \%$ [Sunset optical] to $+50 \%$ [IMPROVE EC]) than for summer (from $-22 \%$ [photoacoustic] to $+27 \%$ [MAAP]). The distribution of differences shows that $>85 \%$ of the samples are within \pm 2 precision intervals and $>90 \%$ of the samples are within \pm 3 precision intervals. All of the samples are within \pm 1 precision interval for the aethalometer in both the winter and annual periods and for the MAAP in summer.

\section{Seasonal Variation}

As shown in Figure 1, monthly averaged BC or EC concentrations were $\sim 2.2$ to 3.4 times higher during winter than summer. This is because of higher BC or EC contributions from traffic emissions in cold conditions, heating (including RWC), and accumulation of pollutants in a shallow surface layer during non-daylight hours. $\mathrm{PM}_{2.5}$ $\mathrm{BC}$ and EC concentrations among different methods differed by as much as a factor of 5 during the winter, with IMPROVE EC being the highest and R\&P 5400 EC being the lowest. Despite their similarities, the three thermal methods (IMPROVE, Sunset, and R\&P 5400) yielded monthly EC concentrations ranging from $0.2 \mu \mathrm{g} / \mathrm{m}^{3}$ (Sunset) to $3.1 \mu \mathrm{g} / \mathrm{m}^{3}$ (IMPROVE), with 3-fold higher EC concentrations in winter $\left(1.39 \mathrm{ug} / \mathrm{m}^{3}\right)$ than in summer $(0.46$ $\left.\mu \mathrm{g} / \mathrm{m}^{3}\right)$. Different temperature- and charring-correction protocols give different values of EC at Fresno. ${ }^{17,29}$

The three optical methods (MAAP, 7-AE, and Sunset optical) yielded monthly BC concentrations from 0.25 $\mu \mathrm{g} / \mathrm{m}^{3}$ (Sunset) to $2.38 \mu \mathrm{g} / \mathrm{m}^{3}$ (15.5 $\mathrm{Mm}^{-1}$; MAAP), also approximately three times higher in winter $\left(1.42 \mathrm{ug} / \mathrm{m}^{3}\right)$ than in summer $\left(0.54 \mu \mathrm{g} / \mathrm{m}^{3}\right)$. The monthly averaged $\mathrm{PAH}$ concentration was consistent with the variation of $\mathrm{BC}$ or EC concentrations, with $\mathrm{PAH}$ concentrations six times higher in winter than summer. 

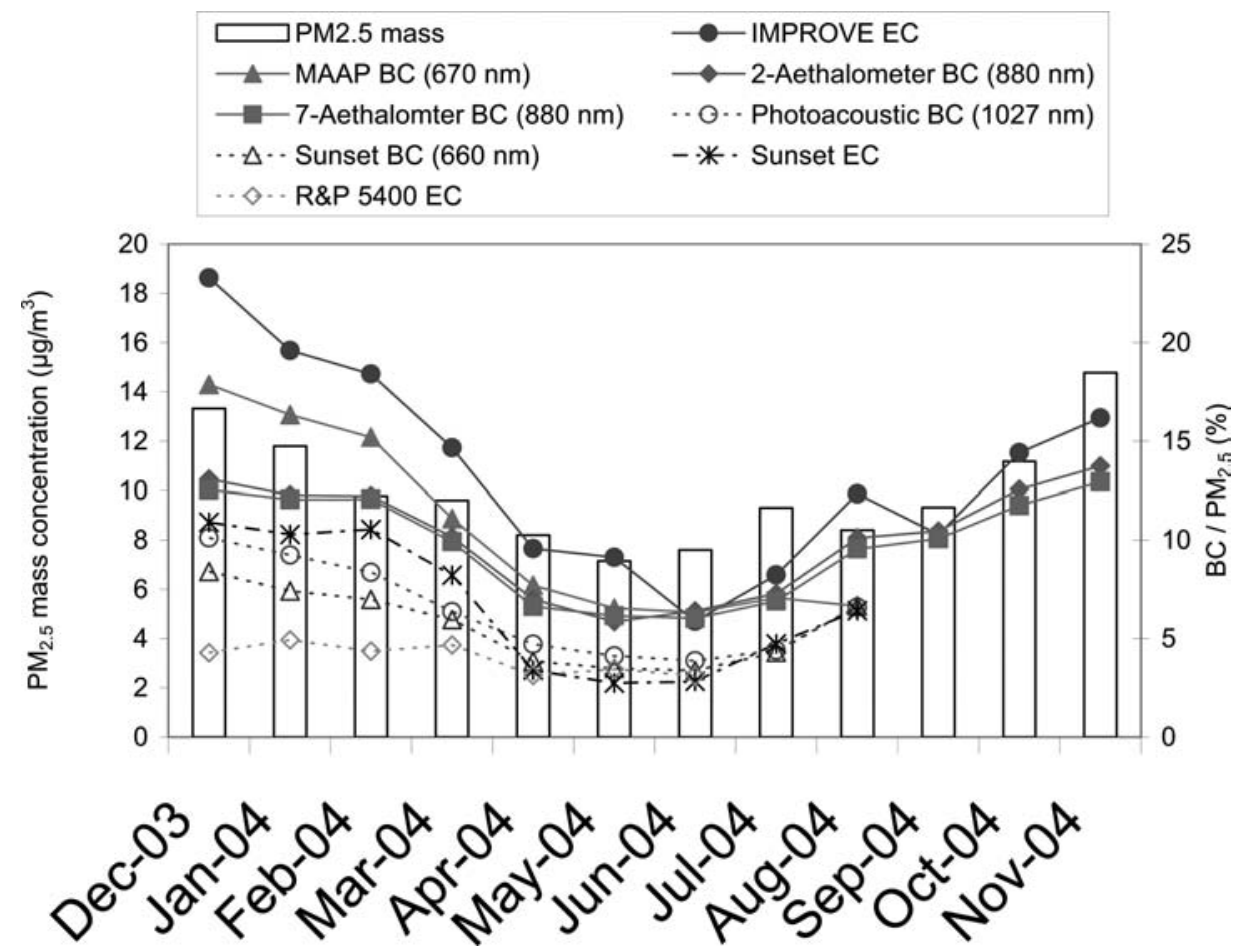

Figure 2. Monthly averages of $P M_{2.5}$ by TEOM and the ratio of $B C$ or $E C$ to $P M_{2.5}$ by IMPROVE, by MAAP $(\lambda=670 \mathrm{~nm})$, by 2-AE $(\lambda=880$ $\mathrm{nm})$, by $7-\operatorname{AE}(\lambda=880 \mathrm{~nm})$, by photoacoustic instrument $(\lambda=1047 \mathrm{~nm})$, by Sunset optical $(\lambda=660 \mathrm{~nm})$, by Sunset thermal, or by R\&P 5400 .

Ultrafine particle-number concentrations in the 3-84 $\mathrm{nm}$ size range $[\mathrm{N}(3-84 \mathrm{~nm})]$ were higher during the summer, whereas the accumulation mode particle-number concentrations in the 84-407 $\mathrm{nm}$ range followed the BC or EC seasonal pattern. Watson et al.47,51 observed frequent secondary ultrafine particle events during late spring through early fall. BC or EC are derived from primary emissions that accumulate during the winter when dispersion is low. ${ }^{50}$

Figure 2 shows how $\mathrm{BC}$ and $\mathrm{EC}$ concentrations varied with $\mathrm{PM}_{2.5}$ throughout the year. The ratio of $\mathrm{BC}$ or $\mathrm{EC}$ to $\mathrm{PM}_{2.5}$ ranged from $7 \%$ to $23 \%$ during winter and from 3\% to $12 \%$ during summer (exclusive of the R\&P 5400). Figure 3 shows how OC/EC ratios varied throughout the year. $\mathrm{PM}_{2.5}$ OC/EC ratios were $>78 \%$ higher during the summer (5.7) than during winter (3.2). This may result from (1) many EC concentrations during summer that were near the lower quantifiable limits, resulting in higher uncertainty in the denominator (EC concentrations were $<1 \mu \mathrm{g} / \mathrm{m}^{3}$ for $\sim 75 \%$ of the days during summer); (2) higher contributions from secondary organic aerosol (SOA) during summer; (3) larger contributions from cold-vehicle starts during winter, which produce larger portions of EC in the exhaust; and (4) contributions from summertime forest fires in the surrounding mountains.

Ultrafine $\mathrm{SOA}^{47,51}$ in relation to carbon levels is examined in Figure 4. $\mathrm{N}(84-407 \mathrm{~nm})$ was reasonably correlated $(r \sim 0.75$ to 0.78$)$ with $\mathrm{BC}$ concentration regardless of the season. However, $\mathrm{N}(3-84 \mathrm{~nm})$ was not related to $\mathrm{BC}$ levels in summer, consistent with condensation of organic vapors on sulfuric acid nuclei formed by photochemical.

\section{Mass Absorption Efficiencies}

The 24-hr averaged $b_{\text {abs }}$ from the MAAP, the 7-AE, and the photoacoustic analyzer were compared with filter-based IMPROVE EC to estimate $\sigma_{\text {abs }}$ applicable to the Fresno aerosol. As shown in Figure $5, \sigma_{\text {abs }}$ is $5.5 \mathrm{~m}^{2} / \mathrm{g}$ for MAAP $(670 \mathrm{~nm}), 10 \mathrm{~m}^{2} / \mathrm{g}$ for $7-\mathrm{AE}(880 \mathrm{~nm})$, and $2.3 \mathrm{~m}^{2} / \mathrm{g}$ for the photoacoustic analyzer $(1047 \mathrm{~nm})$; these values are substantially different from the assumed values of $6.5,16.6$, and $5 \mathrm{~m}^{2} / \mathrm{g}$ for the MAAP, 7-AE, and photoacoustic analyzer, respectively. The wavelength dependence of $b_{\text {abs }}(\lambda)$ and $\sigma_{\mathrm{abs}}(\lambda)$ and the different exponents $(\alpha)$ in the $\lambda^{-\alpha}$ scaling factor, owing to changing particle compositions and shapes, lead to different relationships between BC and $b_{\text {abs }}$. Table 4 compares $\sigma(670 \mathrm{~nm})$ for $\lambda^{-1}, \lambda^{-2}$ (typical of biomass burning ${ }^{7}$ ), and $\lambda^{-2.7}$ (found in ambient Denver, $\mathrm{CO}$, aerosol by Moosmüller et al. ${ }^{52}$ ) for these instruments. The $\sigma_{\mathrm{abs}}(670 \mathrm{~nm})$ values for the $7-\mathrm{AE}$ and photoacoustic analyzer increase by a factor of 3 with $\alpha$ increasing from 1 to 2.7. At $\alpha=2, \sigma_{\text {abs }}(670 \mathrm{~nm})$ values for the 7-AE and photoacoustic analyzer differ only by 4 and $12 \%$ from the default $\sigma_{\mathrm{abs}}$, respectively. With $\lambda^{-2}$ scaling, the MAAP and photoacoustic analyzer had similar $\sigma_{\text {abs }}(670 \mathrm{~nm})$ values of 5.5 and $5.6 \mathrm{~m}^{2} / \mathrm{g}$, respectively.

Comparison of daily averaged 7-AE values with $\mathrm{BC}$ values at $\lambda=370 \mathrm{~nm}$ versus $\lambda=880 \mathrm{~nm}$ (Figure 6) shows that the built-in $\lambda^{-1}$ scaling is consistent during summer, whereas a $\lambda^{-1.3}$ better approximates the situation during winter. As shown in Table 2, aethalometer $(\lambda=880 \mathrm{~nm})$ and photoacoustic analyzer $(\lambda=1047 \mathrm{~nm}) \mathrm{BC}$ values were correlated $(r=0.95-0.99)$ for winter and summer. Comparison between the aethalometer $B C$ value at $\lambda=950 \mathrm{~nm}$ and photoacoustic BC yielded similar results. Absorption at longer wavelengths is less prone to deviation than 


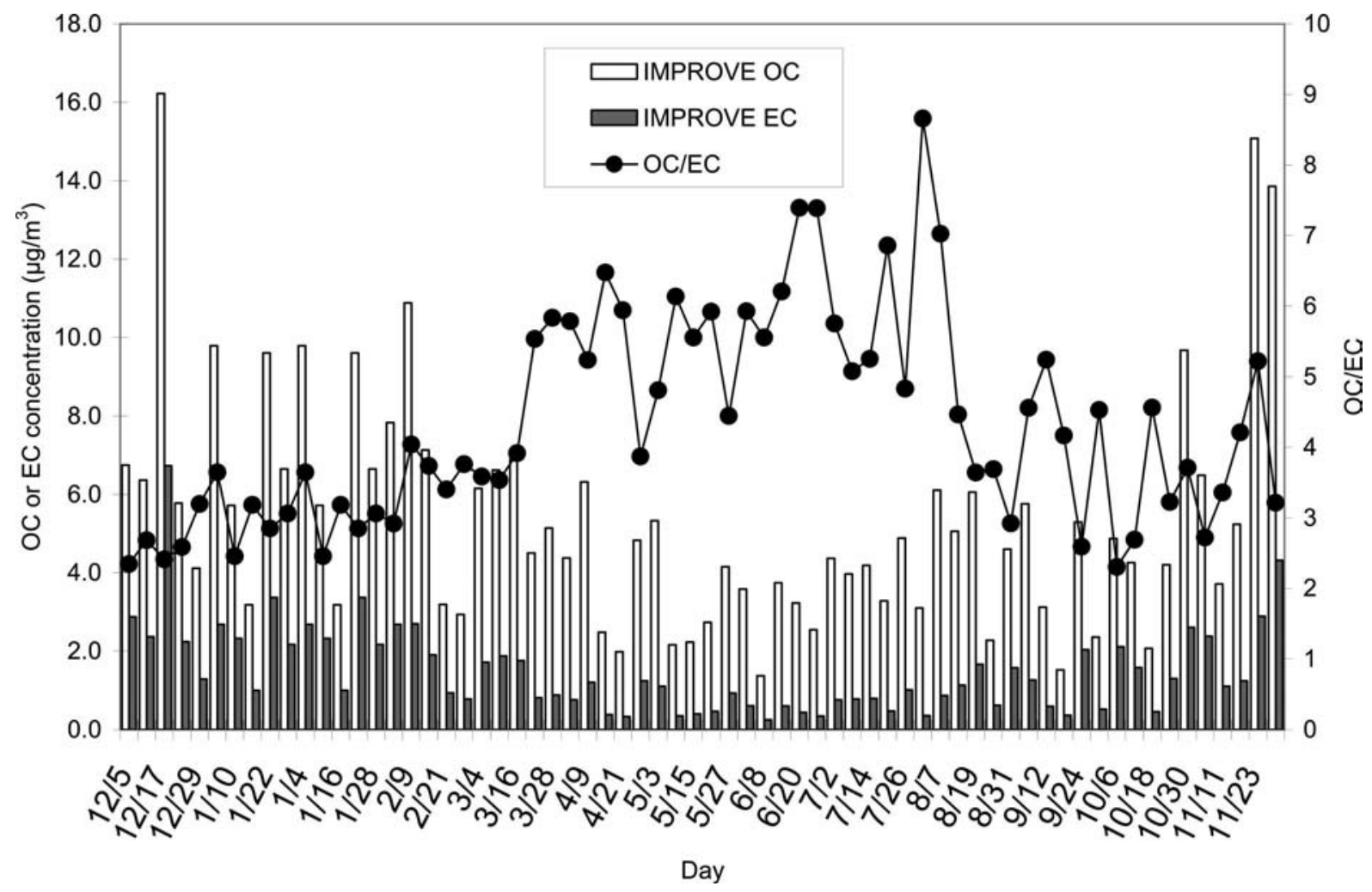

Figure 3. Twenty-four hour averages of $O C$ and $E C$ concentrations, and the OC/EC ratio measured by the DRI/OGC TOR carbon analyzer following the IMPROVE protocol for the period of December 2003 to November 2004.

absorption at shorter wavelengths. The assumed aethalometer $\sigma_{\text {abs }}(880 \mathrm{~nm})$ of $16.6 \mathrm{~m}^{2} / \mathrm{g}$ may not apply because of a lack of consideration of multiple scattering effects in the aethalometer. This is evident in Figure $7 \mathrm{a}$, as $7-\mathrm{AE}$ $b_{\text {abs }}(670 \mathrm{~nm})$ ranges from 2.63 (winter) to 3.38 (summer) times higher than the MAAP $b_{\text {abs }}$, although they are highly correlated $(r=0.98-0.99)$. As shown in Figure $7 \mathrm{~b}$, MAAP $b_{\text {abs }}$ is 1.52 (winter) to 1.23 (summer) times higher than the photoacoustic $b_{\text {abs }}$, still with a high correlation of 0.96-0.99. Better regression slopes of 1.33 (winter) and 1.07 (summer) can be obtained for the MAAP versus photoacoustic comparison if $\alpha=1.3$ is used (determined by Schnaiter et al. ${ }^{25}$ with diesel exhaust).

As noted earlier, the $\sigma_{\text {abs }}(1047 \mathrm{~nm})$ of $5 \mathrm{~m}^{2} / \mathrm{g}$ for the photoacoustic analyzer was derived from simultaneous measurements of diesel exhaust by IMPROVE EC. 40 As shown in Tables 2 and 3, this is not an appropriate assumption for the Fresno summer or winter aerosols. The 5 $\mathrm{m}^{2} / \mathrm{g}$ assumption is also inconsistent with the suggestion of Bond and Bergstrom ${ }^{14}$ cited above for fresh particle emissions, which yields a 1 SD range of $3.3-4.6 \mathrm{~m}^{2} / \mathrm{g}$ at $\lambda=1047 \mathrm{~nm}$ assuming a $\lambda^{-1}$ scaling. This range is $1.7-2.5$ $\mathrm{m}^{2} / \mathrm{g}$ with a $\lambda^{-2}$ scaling. An $\alpha$ between 1 and 2 might be more appropriate for mixed and aged aerosol such as that found at the Fresno Supersite.

It is evident that wavelength has an important effect on the conversion of $b_{\text {abs }}$ to BC. BC values obtained at different wavelengths might be useful in separating vegetative burning from other sources by use of receptor models. ${ }^{53-55}$

\section{Diurnal Variations of the Single Scattering Albedo}

The single scattering albedo $\left(\omega=b_{\text {scat }} /\left[b_{\text {scat }}+b_{\text {abs }}\right]\right)$ was calculated using $b_{\text {scat }}(530 \mathrm{~nm})$ values obtained by nephelometer and $b_{\text {abs }}$ (scaled from 1047 to $530 \mathrm{~nm}$ assuming $\lambda^{-1}$ ) values obtained by the photoacoustic analyzer. Higher values of daily $\omega$ were observed in winter (0.89) than in summer $(0.80)$, consistent with particles containing more scattering species during winter. Higher $\mathrm{RH}$ in winter increases $b_{\text {scat }}$ and therefore contributes to the higher $\omega$. As shown in Figure 8, in winter the lowest $\omega$ occurred during the early morning rush hour of $\sim 7: 00$ a.m. Pacific Standard Time (PST) and at $\sim 8: 00$ p.m. PST. In summer, the lowest $\omega$ occurred at $\sim 6: 00$ a.m. and at 7:00 p.m. PST. Times of low $\omega$ coincided with the peak $b_{\text {abs }}$ occurrences. Although the evening $b_{\text {abs }}$ peak was higher and broader than the morning $b_{\text {abs }}$ peak in winter, the values of $\omega$ were comparable during both seasons.

\section{Diurnal Variations of BC Concentrations}

As shown in Figure 9, the dual peaks for hourly average BC levels were 7:00-8:00 a.m. PST and 8:00-10:00 p.m. PST in winter. The large evening peak persisted through midnight and early morning of the following day. This is consistent with increased emissions from morning and evening traffic and from RWC emissions that accumulate under the surface inversion during winter evenings. ${ }^{50}$ In summer, the morning BC peak occurred at $\sim 6: 00$ a.m. PST with a small evening peak at $\sim 8: 00$ p.m. PST. The times of the peak concentrations of $\mathrm{PAH}, \mathrm{NO}_{\mathrm{x}}$, and $\mathrm{CO}$ coincided 


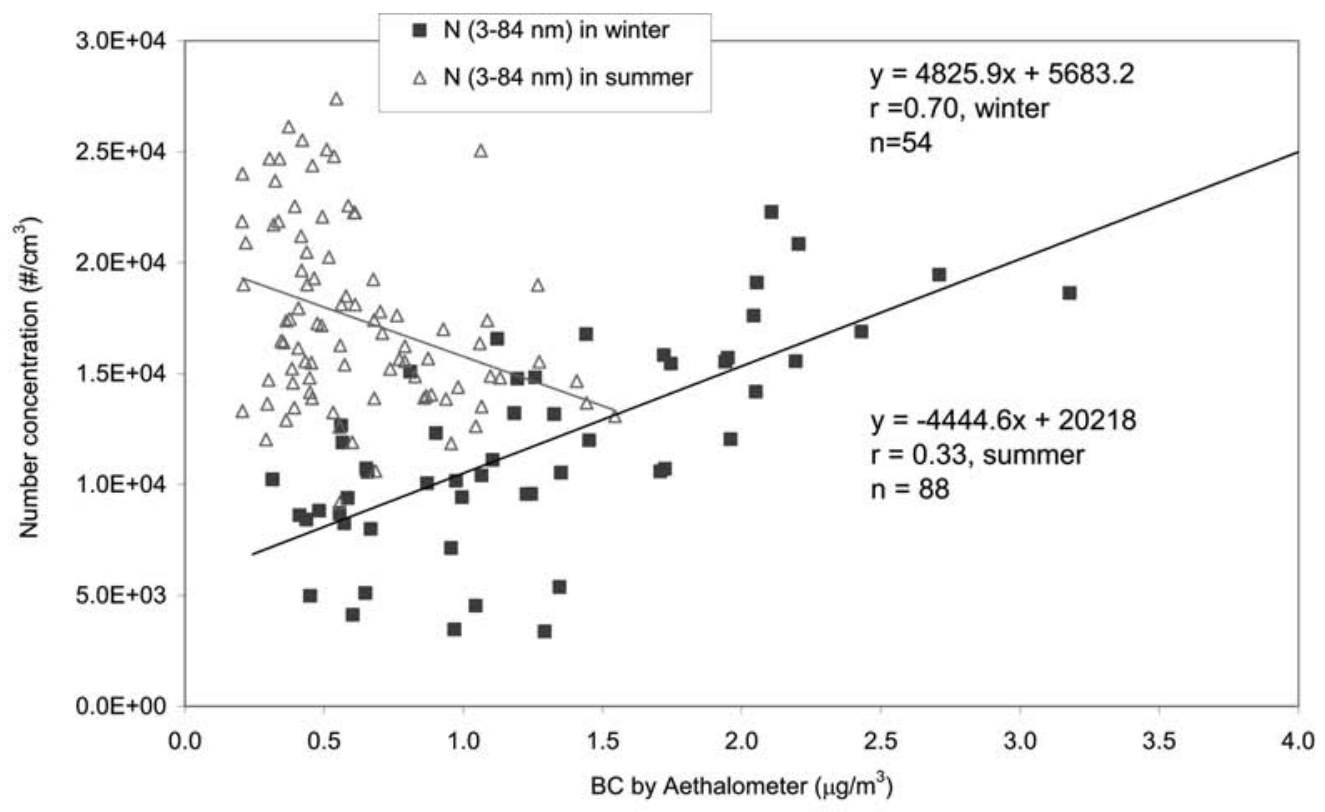

(a)

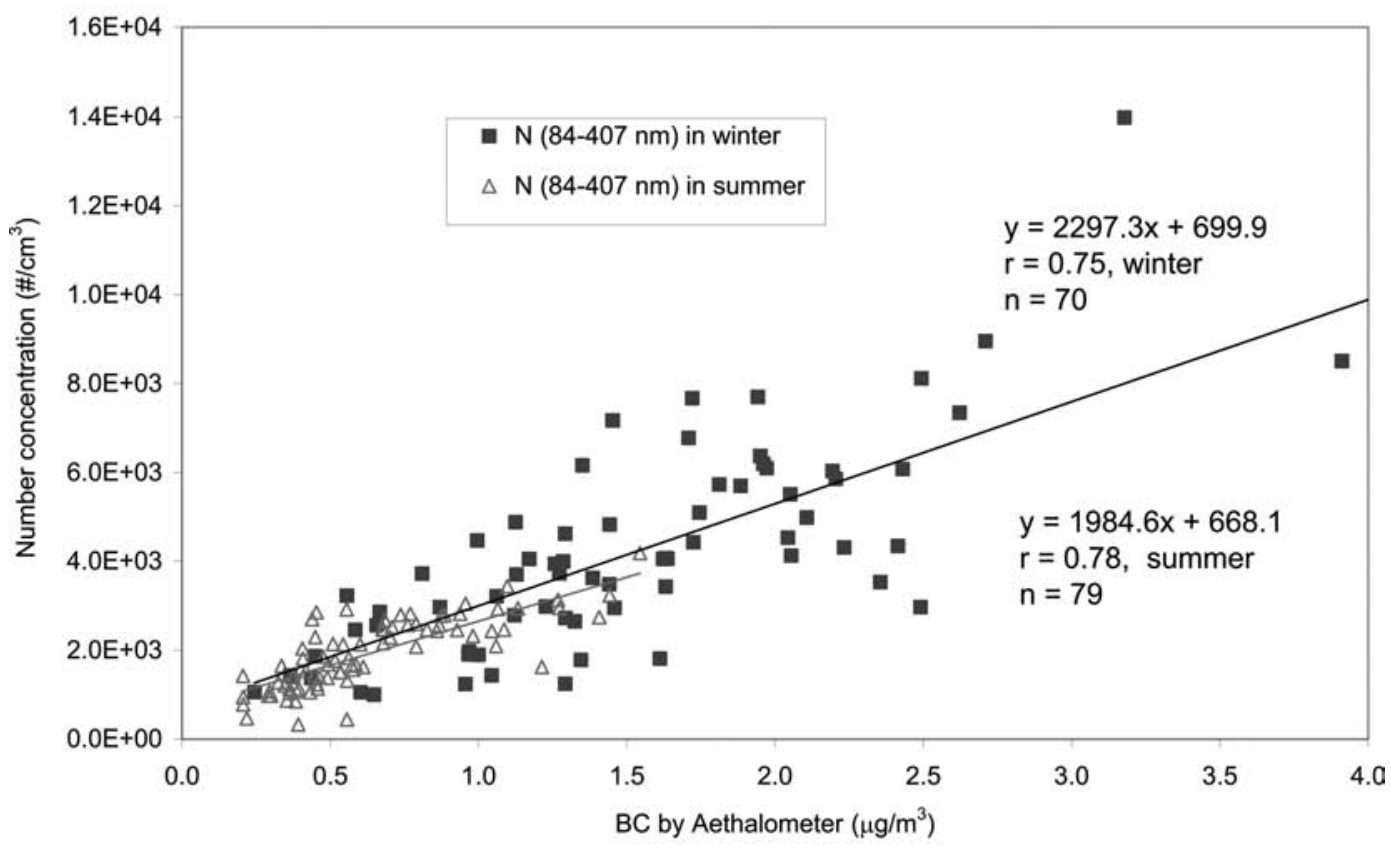

(b)

Figure 4. Particle number concentrations in the size ranges of (a) $3-84 \mathrm{~nm}$ and (b) $84-407 \mathrm{~nm}$ by the SMPS versus BC concentration by $7-A E(\lambda=880 \mathrm{~nm})$ for daily average in winter (December 2003 to February 2004) and summer (June to August 2004).

with the BC peak, and these followed similar seasonal patterns (i.e., the evening peak was more dominant in winter than in summer). The morning $\mathrm{PM}_{2.5}$ peak lagged behind the BC peak by 1 to $2 \mathrm{hr}$. $\mathrm{PM}_{2.5} \mathrm{NO}_{3}{ }^{-}$levels increased after 7:00 a.m. PST in winter. The time for increasing $\mathrm{NO}_{3}{ }^{-}$is consistent with times for increasing temperature and decreasing $\mathrm{BC}, \mathrm{NO}_{\mathrm{x}}$, and $\mathrm{CO}$. This is consistent with $\mathrm{NO}_{3}{ }^{-}$formation above the surface layer with downward mixing when the layers couple. ${ }^{50}$ During summer, the $\mathrm{NO}_{3}{ }^{-}$concentrations increased until $\sim 8: 00$ a.m. PST and then decreased until the late afternoon, consistent with evaporation as temperatures increase.

\section{CONCLUSIONS}

$\mathrm{PM}_{2.5} \mathrm{BC}$ or EC concentrations at the Fresno Supersite are higher in winter than in summer. This is consistent with primary combustion emissions from traffic and home heating that accumulate under a shallow surface layer during winter nights. Similar seasonal patterns are observed for $\mathrm{PM}_{2.5}$ mass, $\mathrm{NO}_{3}{ }^{-}, \mathrm{PAH}, \mathrm{NO}_{\mathrm{x}}, \mathrm{CO}, \omega$, and 


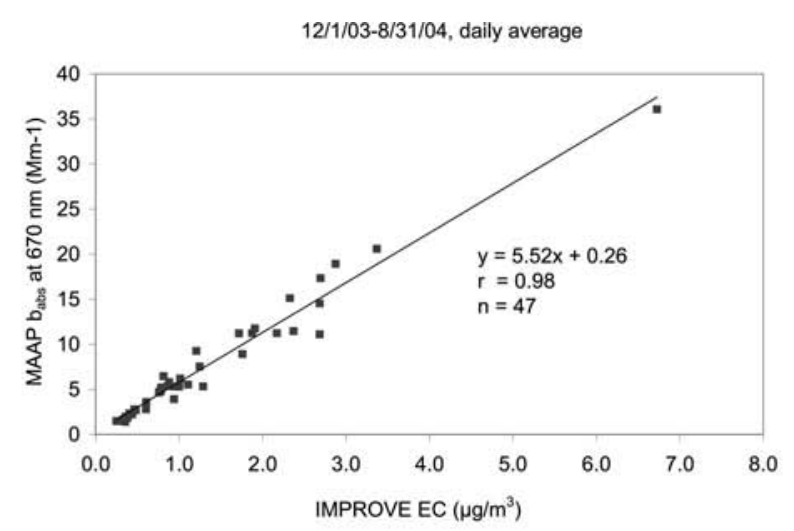

(a)

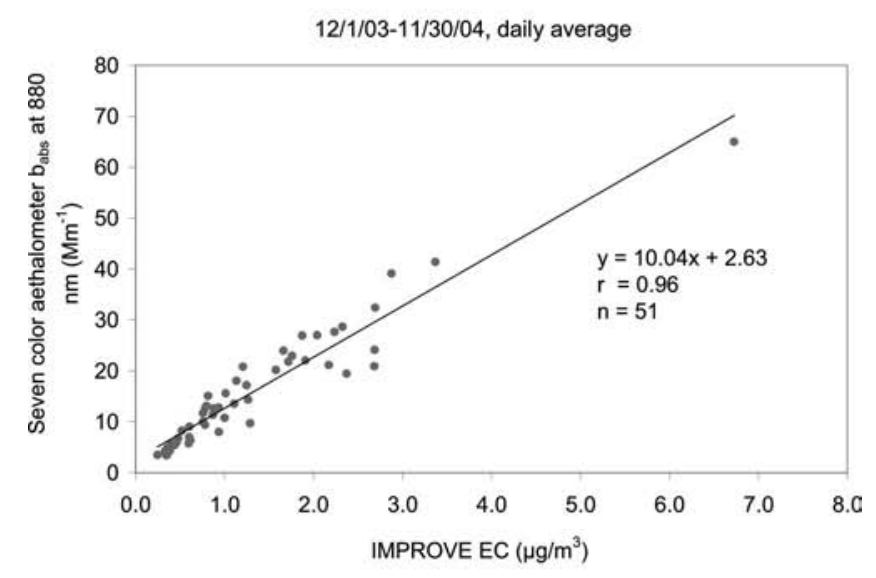

(b)

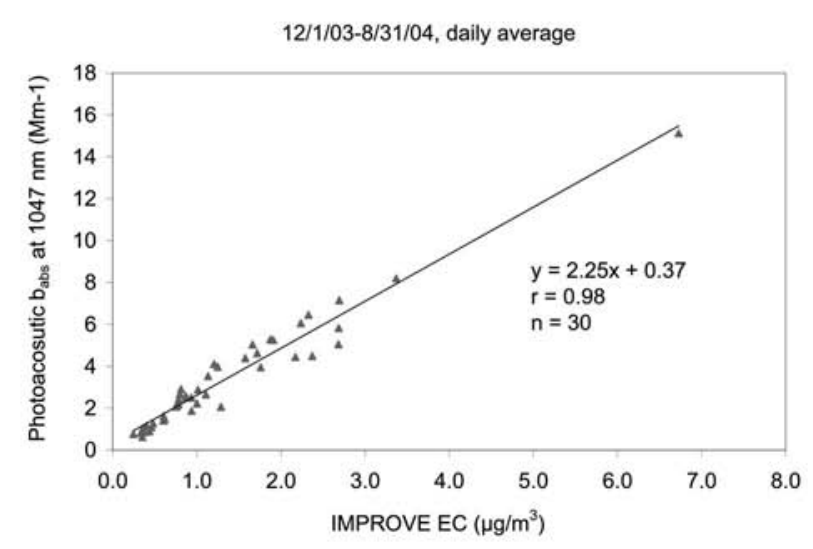

(c)

Figure 5. Mass absorption efficiencies calculated with (a) MAAP $(\lambda=670 \mathrm{~nm})$, (b) 7-AE $(\lambda=880 \mathrm{~nm})$, and (c) photoacoustic analyzer $(\lambda=1047 \mathrm{~nm})$ versus IMPROVE EC concentrations. The aethalometer light attenuation is reported as light absorption without any calibration factor.

number concentration for particles in the accumulation mode $[\mathrm{N}(84-407 \mathrm{~nm})]$. The diurnal pattern of $\mathrm{BC}$ is consistent with those for $\mathrm{PAH}, \mathrm{NO}_{\mathrm{x}}$, and $\mathrm{CO}$, indicating that primary combustion emissions accumulate during early morning and night and decrease as the mixing layer increases, especially during the winter. Higher ratios of BC at $\lambda=370 \mathrm{~nm}$ to $\mathrm{BC}$ at $\lambda=880 \mathrm{~nm}$ occur during the winter, consistent with a larger contribution from RWC that absorbs more in the UV part of the spectrum. The number of ultrafine particles $(3-84 \mathrm{~nm})$ and the OC/EC ratio are lower during winter than summer, both of which are consistent with formation of SOA through vapor condensation.

Compared with IMPROVE EC, mass absorption efficiencies for Fresno are $5.5 \mathrm{~m}^{2} / \mathrm{g}$ for the MAAP at $670 \mathrm{~nm}$, $10 \mathrm{~m}^{2} / \mathrm{g}$ for the aethalometer at $880 \mathrm{~nm}$, and $2.3 \mathrm{~m}^{2} / \mathrm{g}$ for the photoacoustic analyzer at $1047 \mathrm{~nm}$. These differ from the assumed values of $6.5 \mathrm{~m}^{2} / \mathrm{g}$ for the MAAP, $16.6 \mathrm{~m}^{2} / \mathrm{g}$ for the aethalometer, and $5 \mathrm{~m}^{2} / \mathrm{g}$ for the photoacoustic analyzer.

Intercomparisons show good correlations among all $\mathrm{BC}$ or EC measures except for the R\&P $5400 \mathrm{EC}$, but with slopes ranging from 0.2 to 2 . The degree of comparability differed between winter and summer, reinforcing the difference in aerosol composition with the season; $\sigma_{\text {abs }}$ does not scale as $\lambda^{-1}$ at Fresno.

\section{ACKNOWLEDGMENTS}

The Fresno Supersite is a cooperative effort between the California Air Resources Board (ARB) and the DRI. Sponsorship is provided by the U.S. Environmental Protection Agency through the Cooperative Institute for Atmospheric Sciences and Terrestrial Applications (CIASTA) of the National Oceanic and Atmospheric Administration and the California Regional Particulate Air Quality Study (CRPAQS) under the management of Ms. Karen Magliano of the ARB. This work was partially supported by U.S. Environmental Protection Agency STAR Grant No. RD83108601-0. The conclusions are those of the authors and do not necessarily reflect the views of the sponsoring agencies. Any mention of commercially available products and supplies does not constitute an endorsement of those products and supplies. The authors thank Scott Scheller of the ARB and Dr. Susanne Hering of Aerosol Dynamics, Inc., for their efforts in maintaining the monitoring instruments. Dr. John Bowen, Steve Kohl, and Ms. Barbara Hinsvark of DRI assisted in field coordination, laboratory operations, and data processing of Supersite measurements. Ms. Jo Gerrard and Tim Richard of DRI assisted with assembling and editing the manuscript.

\section{REFERENCES}

1. Watson, J.G. Visibility: Science and Regulation; J. Air \& Waste Manage. Assoc. 2002, 52, 628-713.

2. Watson, J.G. Visibility: Science and Regulation - A Summary of the 2002 Critical Review; EM 2002, 8, 36-43.

3. Jacobson, M.Z. Control of Fossil-Fuel Particulate Black Carbon plus Organic Matter, Possibly the Most Effective Method of Slowing Global Warming; J. Geophys. Res. 2002, 107, ACH 16-1-ACH 16-22.

4. Vedal, S. Critical Review - Ambient Particles and Health: Lines That Divide; J. Air \& Waste Manage. Assoc. 1997, 47, 551-581.

5. Watson, J.G.; Chow, J.C.; Chen, L.-W.A. Summary of Organic and Elemental Carbon/Black Carbon Analysis Methods and Intercomparisons; Aerosol Air Qual. Res. 2005, 1, 69-102.

6. Horvath, H. Atmospheric Light Absorption - A Review; Atmos. Environ. 1993, 27A, 293-317.

7. Kirchstetter, T.W.; Novakov, T.; Hobbs, P.V. Evidence That the Spectral Dependence of Light Absorption by Aerosols Is Affected by Organic Carbon; J. Geophys. Res. 2004, 109, D21208.

8. Bond, T.C.; Anderson, T.L.; Campbell, D.E. Calibration and Intercomparison of Filter-based Measurements of Visible Light Absorption by Aerosols; Aerosol Sci. Technol. 1999, 30, 582-600. 
Table 4. Comparisons of assumed absorption coefficients with measured values and wavelength-corrected absorption efficiencies.

\begin{tabular}{|c|c|c|c|c|c|}
\hline Instruments & $\begin{array}{c}\text { Assumed } \\
\text { Absorption } \\
\text { Efficiency } \\
\left(\mathrm{m}^{2} / \mathrm{g}\right)^{\mathrm{a}}\end{array}$ & $\begin{array}{c}\text { Fresno Absorption } \\
\text { Efficiency at } \\
\text { Instrument } \lambda \\
\left(\mathrm{m}^{2} / \mathrm{g}\right)^{\mathrm{b}}\end{array}$ & \multicolumn{3}{|c|}{ Estimated Absorption Efficiency } \\
\hline MAAP (670 nm) & 6.5 & 5.5 & 5.5 & 5.5 & 5.5 \\
\hline $7-\mathrm{AE}(880 \mathrm{~nm})$ & $16.6^{d}$ & 10.0 & 13.1 & 17.3 & 27.4 \\
\hline Photoacoustic analyzer (1047 nm) & 5.0 & 2.3 & 3.5 & 5.6 & 11.7 \\
\hline
\end{tabular}

Notes: ${ }^{a}$ Conversion factors assumed to convert light absorption (for MAAP and photoacoustic analyzer) or light attenuation (for 7-AE) to BC concentration; ${ }^{\mathrm{b}}$ Regression slope from light absorption (for MAAP and photoacoustic analyzer) or light attenuation (for 7-AE) vs IMPROVE EC concentration; ${ }^{\circ}$ Based on the Angstrom Power Law with different exponents $\left(b_{\mathrm{abs}} \sim \lambda^{-\alpha}\right): \alpha=1$ by Angstrom Power Law; $\alpha=2$ by Kirchstetter et al. ${ }^{7}$; and $\alpha=2.7$ by Moosmüller et al. 52 ; ${ }^{d}$ Based on $14,625 / \lambda$ at $880 \mathrm{~nm}$; the aethalometer light attenuation $\left(\mathrm{Mm}^{-1}\right)$ is reported as light absorption without any calibration factor in this study.

9. Lindberg, J.D.; Douglass, R.E.; Garvey, D.M. Atmospheric Particulate Absorption and Black Carbon Measurement; Appl. Opt. 1999, 38, 2369-2376.

10. Petzold, A.; Schönlinner, M. Multi-angle Absorption Photometry - A New Method for the Measurement of Aerosol Light Absorption and Atmospheric Black Carbon; J. Aerosol Sci. 2004, 35, 421-441.

11. Fuller, K.A.; Malm, W.C.; Kreidenweis, S.M. Effects of Mixing on Extinction by Carbonaceous Particles; J. Geophys. Res. 1999, 104, 15941-15954.

12. Martins, J.V.; Artaxo, P.; Liousse, C.; Reid, J.S.; Hobbs, P.V.; Kaufman, Y.J. Effects of Black Carbon Content, Particle Size, and Mixing on Light Absorption by Aerosols from Biomass Burning in Brazil; J. Geophys. Res. 1998, 103, 32041-32050.

13. Liousse, C.; Cachier, H.; Jennings, S.G. Optical and Thermal Measurements of Black Carbon Aerosol Content in Different Environments: Variation of the Specific Attenuation Cross-section, Sigma ( $\sigma)$; Atmos. Environ. 1993, 27A, 1203-1211.

14. Bond, T.C.; Bergstrom, R.W. Light Absorption by Carbonaceous Particles: An Investigative Review; Aerosol Sci. Technol. 2006, 40, 27-67.

15. Chow, J.C.; Watson, J.G. $\mathrm{PM}_{2.5}$ Carbonate Concentrations at Regionally Representative Interagency Monitoring of Protected Visual Environment Sites; J. Geophys. Res. 2002, 107, ICC 6-1-ICC 6-9.

16. Cao, J.J.; Lee, S.C.; Zhang, X.Y.; Chow, J.C.; An, Z.S.; Ho, K.F.; Watson, J.G.; Fung, K.K.; Wang, Y.Q.; Shen, Z.X. Characterization of Airborne Carbonate over a Site near Asian Dust Source Regions during Spring 2002 and Its Climatic and Environmental Significance; J. Geophys. Res. 2005, 110, 1-8

17. Chow, J.C.; Watson, J.G.; Chen, L.-W.A.; Arnott, W.P.; Moosmüller, H.; Fung, K.K. Equivalence of Elemental Carbon by Thermal/Optical Reflectance and Transmittance with Different Temperature Protocols; Environ. Sci. Technol. 2004, 38, 4414-4422.

18. Chen, L.-W.A.; Chow, J.C.; Watson, J.G.; Moosmüller, H.; Arnott, W.P. Modeling Reflectance and Transmittance of Quartz-Fiber Filter Samples Containing Elemental Carbon Particles: Implications for Thermal/Optical Analysis; J. Aerosol. Sci. 2004, 35, 765-780.

19. Currie, L.A.; Benner, B.A., Jr.; Cachier, H.; Cary, R.; Chow, J.C.; Druffel, E.R.M.; Eglinton, T.I.; Gustafsson, Ö.; Hartmann, P.C.; Hedges, J.I.; Kessler, J.D.; Kirchstetter, T.W.; Klinedinst, D.B.; Klouda, G.A.; Marolf, J.V.; Masiello, C.A.; Novakov, T.; Pearson, A.; Prentice, K.M.; Puxbaum, H.; Quinn, J.G.; Reddy, C.M.; Schmid, H.; Slater, J.F.; Watson, J.G.; Wise, S.A. A Critical Evaluation of Interlaboratory Data on Total, Elemental, and Isotopic Carbon in the Carbonaceous Particle Reference Material, NIST SRM 1649a; J. Res. Natl. Bur. Stand. (U.S.) 2002, 107, 279-298.

20. Arnott, W.P.; Moosmüller, H.; Rogers, C.F.; Jin, T.; Bruch, R. Photoacoustic Spectrometer for Measuring Light Absorption by Aerosol: Instrument Description; Atmos. Environ. 1999, 33, 2845-2852.

21. Bell, A.G. Production of Sound by Radiant Energy; The Manufacturer and Builder, 1881, 15, 156-158.

22. Bruce, C.W.; Pinnick, R.G. In-Situ Measurements of Aerosol Absorption with a Resonant CW Laser Spectrophone; Appl. Opt. 1977, 16, 1762-1764.

23. Saathoff, H.; Naumann, K.H.; Schnaiter, M.; Schöck, W.; Weingartner, E.; Baltensperger, U.; Krämer, L.; Bozoki, Z.; Pöschl, U.; Niessner, R.; Schurath, U. Carbon Mass Determinations during the AIDA Soot Aerosol Campaign 1999; J. Aerosol Sci. 2003, 34, 1399-1420.

24. Saathoff, H.; Moehler, O.; Schurath, U.; Kamm, S.; Dippel, B.; Mihelcic, D. The AIDA Soot Aerosol Characterisation Campaign 1999; J. Aerosol Sci. 2003, 34, 1277-1296.

25. Schnaiter, M.; Horvath, H.; Mohler, O.; Naumann, K.H.; Saathoff, H.; Schock, O.W. UV-VIS-NIR Spectral Optical Properties of Soot and Soot-containing Aerosols; J. Aerosol. Sci. 2003, 34, 1421-1444.

26. Sheridan, P.J.; Arnott, W.P.; Ogren, J.A.; Andrews, E.; Atkinson, D.B.; Covert, D.S.; Moosmüller, H.; Petzold, A.; Schmid, B.; Strawa, A.W.;
Varma, R.; Virkkula, A. The Reno Aerosol Optics Study: An Evaluation of Aerosol Absorption Measurement Methods; Aerosol. Sci. Technol. 2005, 39, 1-16.

27. Watson, J.G.; Chow, J.C.; Bowen, J.L.; Lowenthal, D.H.; Hering, S.; Ouchida, P.; Oslund, W. Air Quality Measurements from the Fresno Supersite; J. Air \& Waste Manage. Assoc. 2000, 50, 1321-1334.

28. Watson, J.G.; Chow, J.C. Comparison and Evaluation of In-Situ and Filter Carbon Measurements at the Fresno Supersite; J. Geophys. Res. 2002, 107, ICC 3-1-ICC 3-15.

29. Chow, J.C.; Watson, J.G.; Lowenthal, D.H.; Solomon, P.A.; Magliano, K.L.; Ziman, S.D.; Richards, L.W. $\mathrm{PM}_{10}$ and $\mathrm{PM}_{2.5}$ Compositions in California's San Joaquin Valley; Aerosol. Sci. Technol. 1993, 18, 105128.

30. Chow, J.C.; Chen, L.-W.A.; Watson, J.G.; Lowenthal, D.H.; Magliano, K.; Turkiewicz, K.; Lehrman, D. $\mathrm{PM}_{2.5}$ Chemical Composition and Spatiotemporal Variability during the California Regional $\mathrm{PM}_{10} / \mathrm{PM}_{2.5}$ Air Quality Study (CRPAQS); J. Geophys. Res. 2006, in press.

31. Hansen, A.D.A.; Rosen, H.; Novakov, T. The Aethalometer - An Instrument for the Real-Time Measurement of Optical Absorption by Aerosol Particles; Sci. Total Environ. 1984, 36, 191-196.

32. Arnott, W.P.; Hamasha, K.; Moosmüller, H.; Sheridan, P.J.; Ogren, J.A. Towards Aerosol Light-Absorption Measurements with a 7-Wavelength Aethalometer: Evaluation with a Photoacoustic Instrument and 3-Wavelength Nephelometer; Aerosol Sci. Technol. 2005, 39, $17-$ 29.

33. Petzold, A.; Kramer, H.; Schönlinner, M. Continuous Measurement of Atmospheric Black Carbon Using a Multi-angle Absorption Photometer; Environ. Sci. Pollut. Res. 2002, Special Issue, 478-82.

34. Petzold, A.; Schloesser, H.; Sheridan, P.J.; Arnott, W.P.; Ogren, J.A.; Virkkula, A. Evaluation of Multiangle Absorption Photometry for Measuring Aerosol Light Absorption; Aerosol Sci. Technol. 2005, 39, 40-51.

35. VDI Measurement of Soot (Ambient Air) - Thermographic Determination of Elemental Carbon after Thermal Desorption of Organic Carbon; Berein Deutscher: Dusseldorf, Germany, 1999, (2465 Part 2).

36. Schmid, H.P.; Laskus, L.; Abraham, H.J.; Baltensperger, U.; Lavanchy, V.M.H.; Bizjak, M.; Burba, P.; Cachier, H.; Crow, D.; Chow, J.C.; Gnauk, T.; Even, A.; ten Brink, H.M.; Giesen, K.P.; Hitzenberger, R.; Hueglin, C.; Maenhaut, W.; Pio, C.A.; Puttock, J.; Putaud, J.P.; ToomSauntry, D.; Puxbaum, H. Results of the "Carbon Conference" International Aerosol Carbon Round Robin Test: Stage 1; Atmos. Environ. 2001, 35, 2111-2121.

37. Chow, J.C.; Watson, J.G.; Pritchett, L.C.; Pierson, W.R.; Frazier, C.A.; Purcell, R.G. The DRI Thermal/Optical Reflectance Carbon Analysis System: Description, Evaluation and Applications in U.S. Air Quality Studies; Atmos. Environ. 1993, 27A, 1185-1201.

38. Chow, J.C.; Watson, J.G.; Crow, D.; Lowenthal, D.H.; Merrifield, T.M Comparison of IMPROVE and NIOSH Carbon Measurements; Aerosol Sci. Technol. 2001, 34, 23-34.

39. Arnott, W.P.; Moosmüller, H.; Sheridan, P.J.; Ogren, J.A.; Raspet, R.; Slaton, W.V.; Hand, J.L.; Kreidenweis, S.M.; Collett, J.L., Jr. Photoacoustic and Filter-based Ambient Aerosol Light Absorption Measurements: Instrument Comparison and the Role of Relative Humidity; J. Geophys. Res. 2003, 108, AAC 15-1-AAC 15-11.

40. Arnott, W.P.; Zielinska, B.; Rogers, C.F.; Sagebiel, J.; Park, K.; Chow, J.C.; Moosmüller, H.; Watson, J.G.; Kelly, K.; Wagner, D.; Sarofim, A.; Lighty, J.; Palmer, G. Evaluation of 1047 nm Photoacoustic Instruments and Photoelectric Aerosol Sensors in Source-Sampling of Black Carbon Aerosol and Particle Bound PAH's from Gasoline and Diesel Powered Vehicles; Environ. Sci. Technol. 2005, 39, 5398-5406.

41. Bae, M.S.; Schauer, J.J.; Deminter, J.T.; Turner, J.R.; Smith, D.; Cary, R.A. Validation of a Semi-continuous Instrument for Elemental Carbon and Organic Carbon Using a Thermal-Optical Method; Atmos. Environ. 2004, 38, 2885-2893. 


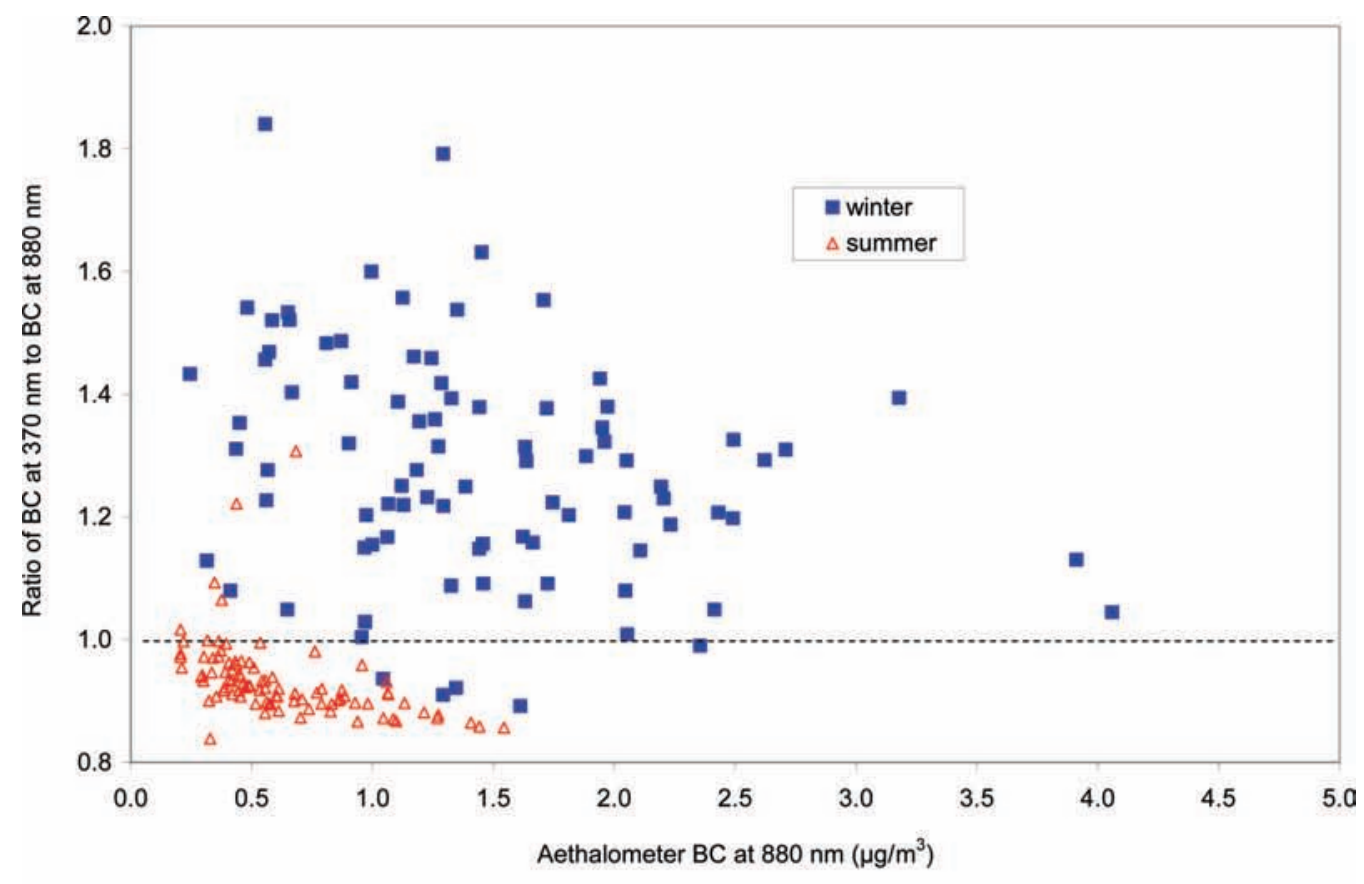

(a)

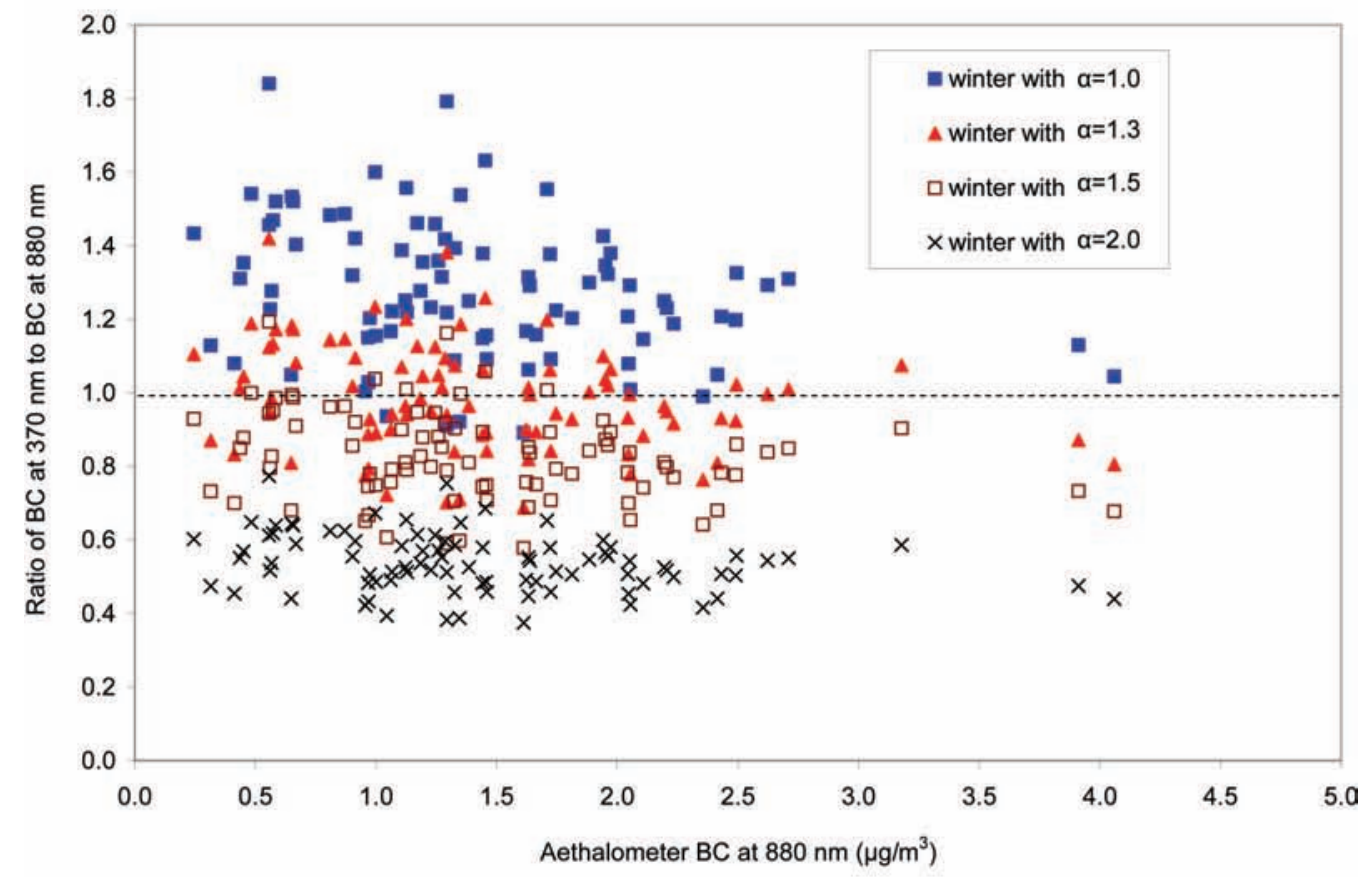

(b)

Figure 6. Ratio of daily averaged $B C$ at the wavelength of $370 \mathrm{~nm}$ versus $880 \mathrm{~nm}$ as a function of the $7-A E B C$ concentration at $\lambda=880 \mathrm{~nm}$ in (a) winter (December 2003 to February 2004) and in summer (June to August 2004), and (b) in winter with different exponents ( $\alpha$ ) in the $\gamma-\alpha$ scaling factor.

42. Jeong, C.H.; Hopke, P.K. Kim, E. Lee, D.W. The Comparison between Thermal-Optical Transmittance Elemental Carbon and Aethalometer Black Carbon Measured at Multiple Monitoring Sites; Atmos. Environ. 2004, 38, 5193-5204.

43. Rupprecht, E.G.; Patashnick, H.; Beeson, D.E.; Green, R.E.; Meyer, M.B. A New Automated Monitor for the Measurement of Particulate Carbon in the Atmosphere. In Proceedings, Particulate Matter: Health and Regulatory Issues, April 4-6, 1995, Cooper, J.A. and Grant, L.D., Eds.; Air and Waste Management Association: Pittsburgh, PA, 1995, pp. 262267.

44. Burtscher, H.; Schmidt-Ott, A. In Situ Measurement of Adsorption and Condensation of a Polyaromatic Hydrocarbon on Ultrafine Carbon 


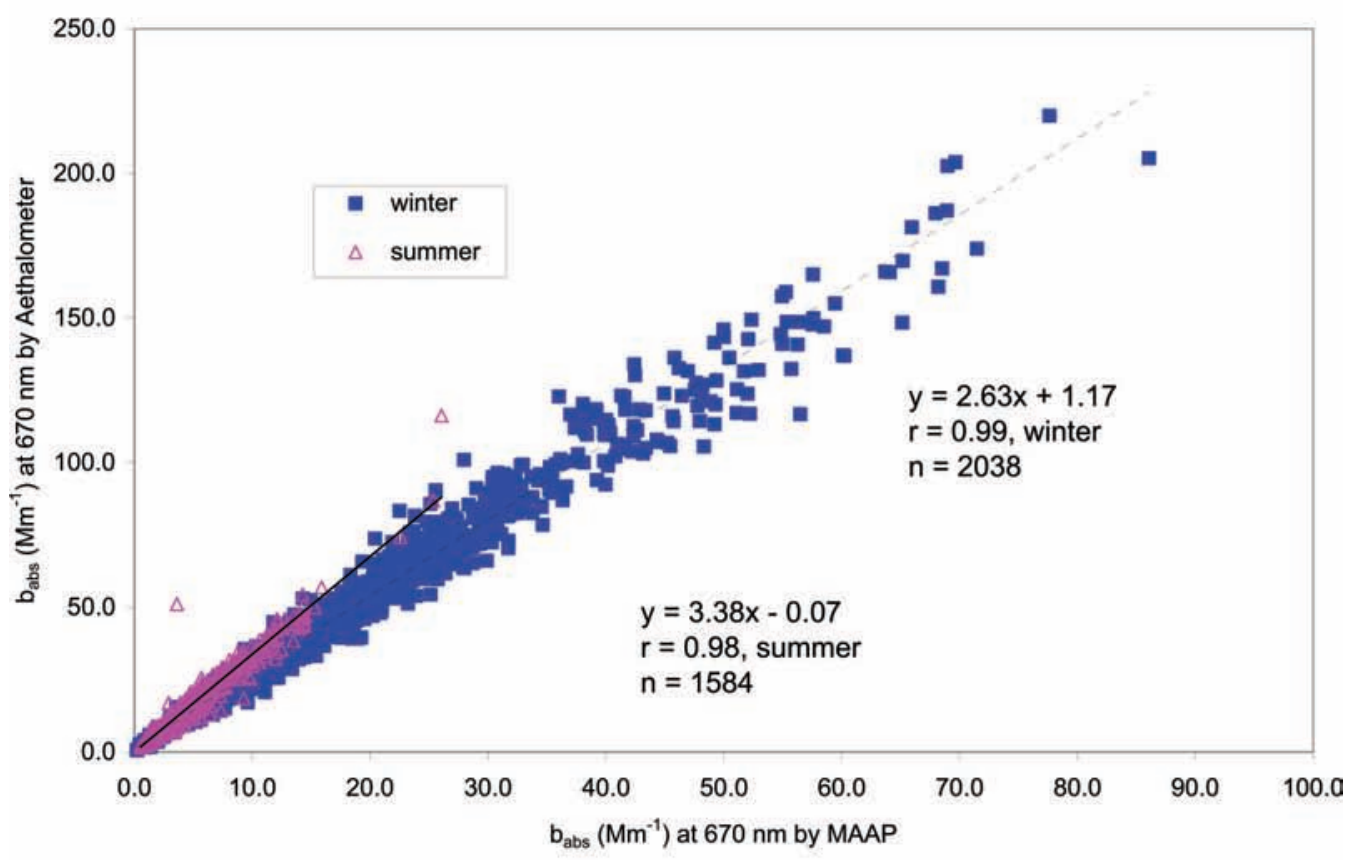

(a)

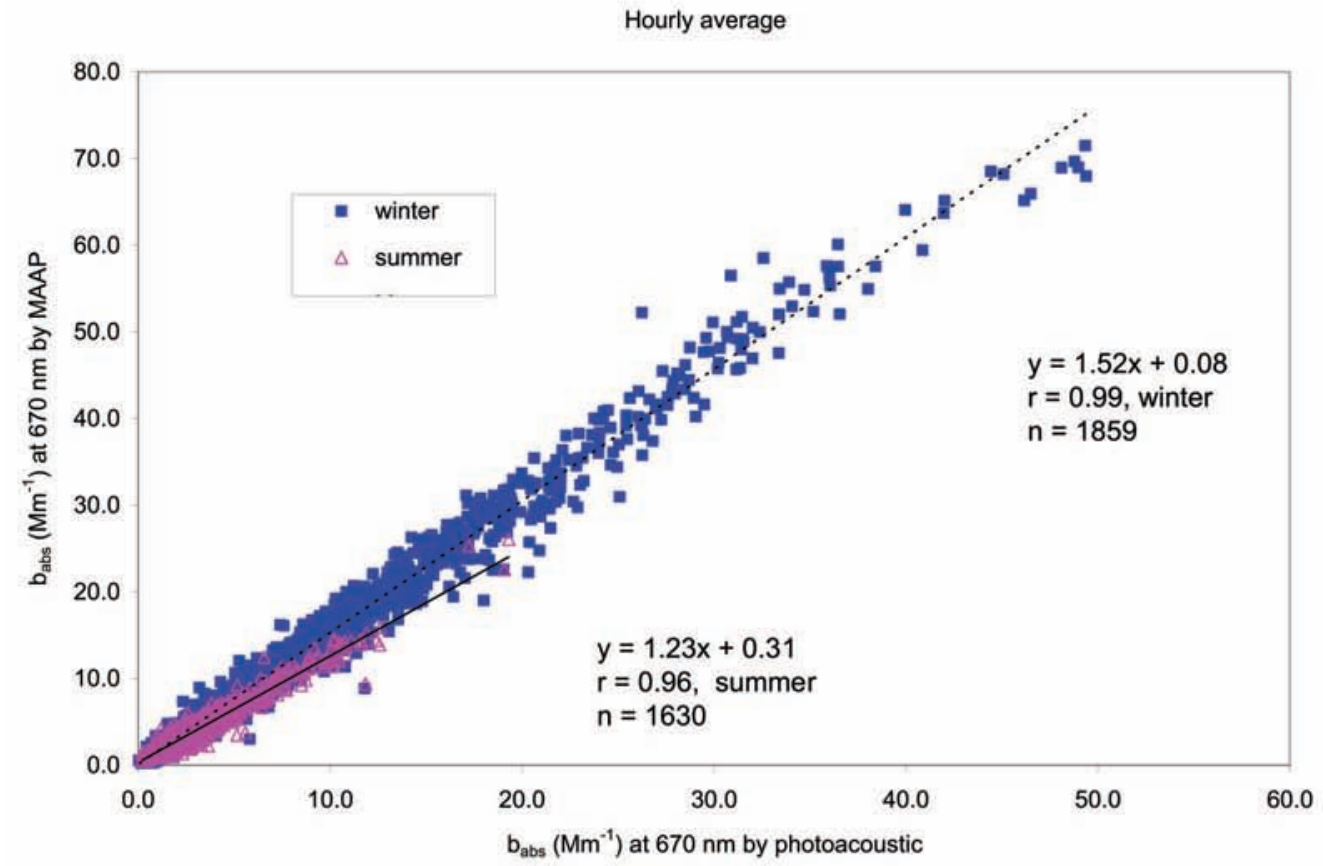

(b)

Figure 7. Hourly averaged (a) $b_{\mathrm{abs}}$ by $7-\mathrm{AE}$ versus $b_{\mathrm{abs}}$ by MAAP at $\lambda=670 \mathrm{~nm}$ and (b) MAAP $b_{\mathrm{abs}}$ vs. photoacoustic $b_{\mathrm{abs}}$ at $\lambda=670 \mathrm{~nm}$ in winter (December 2003 to February 2004) and summer (June to August 2004)

Particles by Measurement of Photoemission; J. Aerosol Sci. 1986, 18, 699.

45. United States Environmental Protection Agency. Revised Requirements for Designation of Reference and Equivalent Methods for $\mathrm{PM}_{2.5}$ and Ambient Air Surveillance for Particulate Matter-Final Rule; Fed. Regist. 1997, 138, 38763-38854.
46. Chow, J.C.; Watson, J.G.; Lowenthal, D.H.; Chen, L.-W.A.; Magliano, K. Particulate Carbon Measurements in California's San Joaquin Valley; Chemosphere, 2006, 62, 337-348.

47. Watson, J.G.; Chow, J.C.; Lowenthal, D.H.; Kreisberg, N.; Hering, S.V. Stolzenburg, M.R. Variations of Nanoparticle Concentrations at the Fresno Supersite. Sci. Total Environ. 2006, 358, 178-187. 


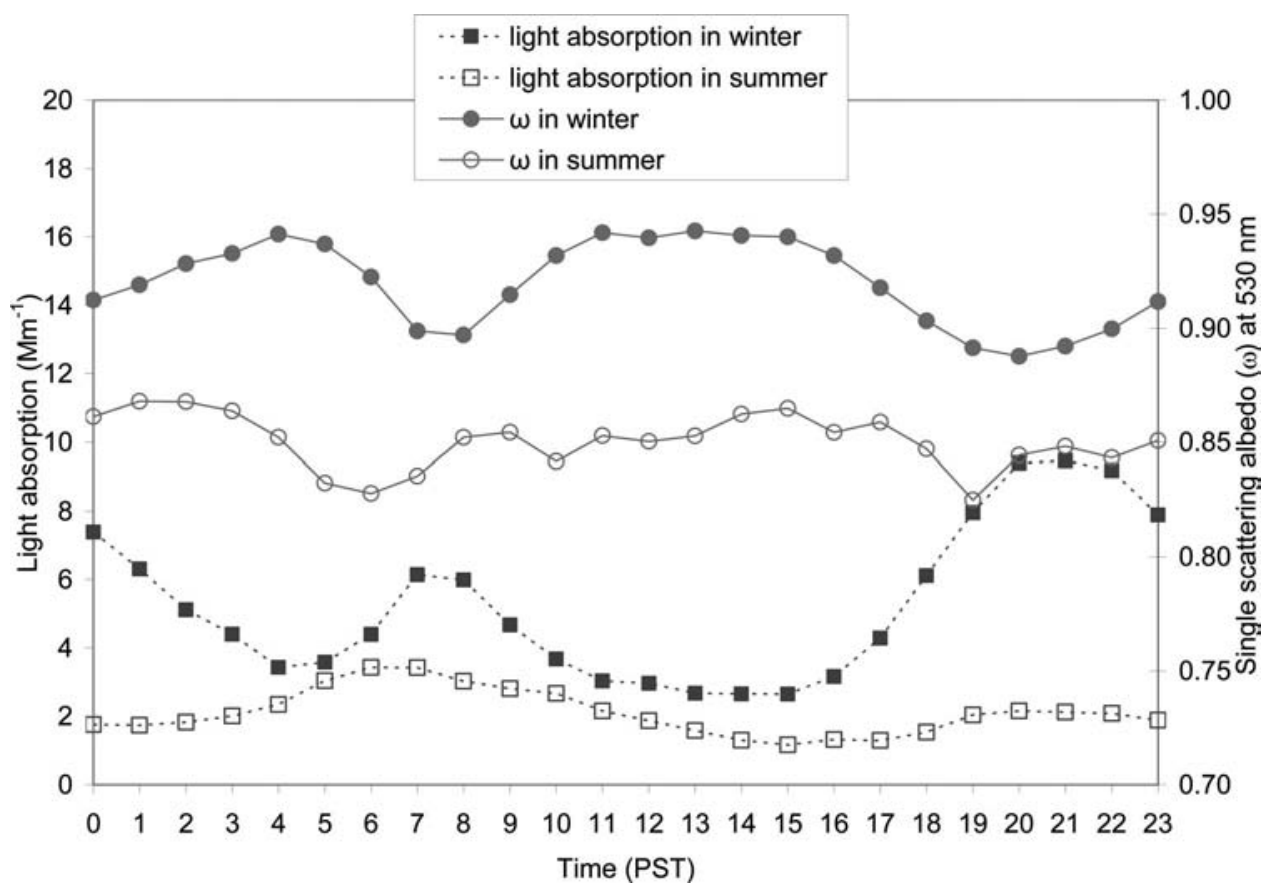

Figure 8. Diurnal variation of the single scattering albedo $(\omega)$ calculated by use of particle light scattering $\left(b_{\text {scat }}\right)$ from the nephelometer $(\lambda=$ $530 \mathrm{~nm})$ and light absorption $\left(b_{\text {abs }}\right)$ from the photoacoustic analyzer $(\lambda=1047 \mathrm{~nm}$ ) averaged by the time of day in winter (December 2003 to February 2004) and summer (June to August 2004).

48. Richards, L.W.; Lehrman, D.E.; Weiss, R.E.; Bush, D.; Watson, J.G.; McDade, C.E.; Magliano, K. Light scattering measurements during the California Regional $\mathrm{PM}_{10} / \mathrm{PM}_{2.5}$ Air Quality Study. In Proceedings, International Specialty Conference on Regional Haze and Global Radiation Balance-Aerosol Measurements and Models: Closure, Reconciliation and Evaluation, Air \& Waste Management Association/American Geophysical Union: Pittsburgh, PA/Washington, DC, 2001.

49. Patashnick, H.; Rupprecht, E.G. Continuous $\mathrm{PM}_{10}$ Measurements Using the Tapered Element Oscillating Microbalance; J. Air \& Waste Manage. Assoc. 1991, 41, 1079-1083.

50. Watson, J.G.; Chow, J.C. A Wintertime $\mathrm{PM}_{2.5}$ Episode at the Fresno, CA, Supersite; Atmos. Environ. 2002, 36, 465-475.

51. Watson, J.G.; Chow, J.C.; Park, K.; Lowenthal, D.H. Nanoparticle and Ultrafine Particle Events at the Fresno Supersite; J. Air \& Waste Manage. Assoc. 2006, 55, 417-430.

52. Moosmüller, H.; Arnott, W.P.; Rogers, C.F.; Chow, J.C.; Frazier, C.A.; Sherman, L.E.; Dietrich, D.L. Photoacoustic and Filter Measurements Related to Aerosol Light Absorption during the Northern Front Range Air Quality Study (Colorado 1996/1997); J. Geophys. Res. 1998, 103, 28149-28157.

53. Watson, J.G.; Chow, J.C.; Houck, J.E. PM $_{2.5}$ Chemical Source Profiles for Vehicle Exhaust, Vegetative Burning, Geological Material, and Coal Burning in Northwestern Colorado during 1995; Chemosphere, 2001, 43, 1141-1151.

54. Watson, J.G.; Zhu, T.; Chow, J.C.; Engelbrecht, J.P.; Fujita, E.M.; Wilson, W.E. Receptor Modeling Application Framework for Particle Source Apportionment; Chemosphere, 2002, 49, 1093-1136.

55. Watson, J.G.; Chow, J.C. Receptor Models for Air Quality Management; $E M$, 2004, 10, 27-36.

\section{About the Authors}

Kihong Park was formerly an assistant research professor at the Desert Research Institute (DRI) and is currently an assistant professor at the Gwangju Institute of Science and Technology. Judith C. Chow and John G. Watson are research professors, Dana Trimble is an associate research scientist, and Prakash Doraiswamy is a post doctoral research associate at DRI. W. Pat Arnott is an associate professor at the University of Nevada, Reno. Kenneth R. Stroud is chief of the Air Quality Surveillance Branch, Kenneth Bowers is an air pollution specialist, and Richard D. Bode is chief of the Health and Exposure Assessment Branch of the California Air Resources Board. Andre Petzold is head of the Atmosphereic Group at the Instutue of Atmoshperic Physics (Deutsches Zentrum fur Luft - und Raumfahrt Oberpfaffenhofen, Institute fur Physic der Atmosphare). Anthonty D. A. Hansen is a staff scientist for the Engineering Division of Lawrence Berkeley National Laboratory. Address correspondence to: Judith C. Chow, Division of Atmospheric Sciences, Desert Research Institute, 2215 Raggio Parkway, Reno, NV 89512; phone: +1-775-674-7050; fax: +1-775-674-7009; e-mail: judy. chow@dri.edu. 
Park et al.

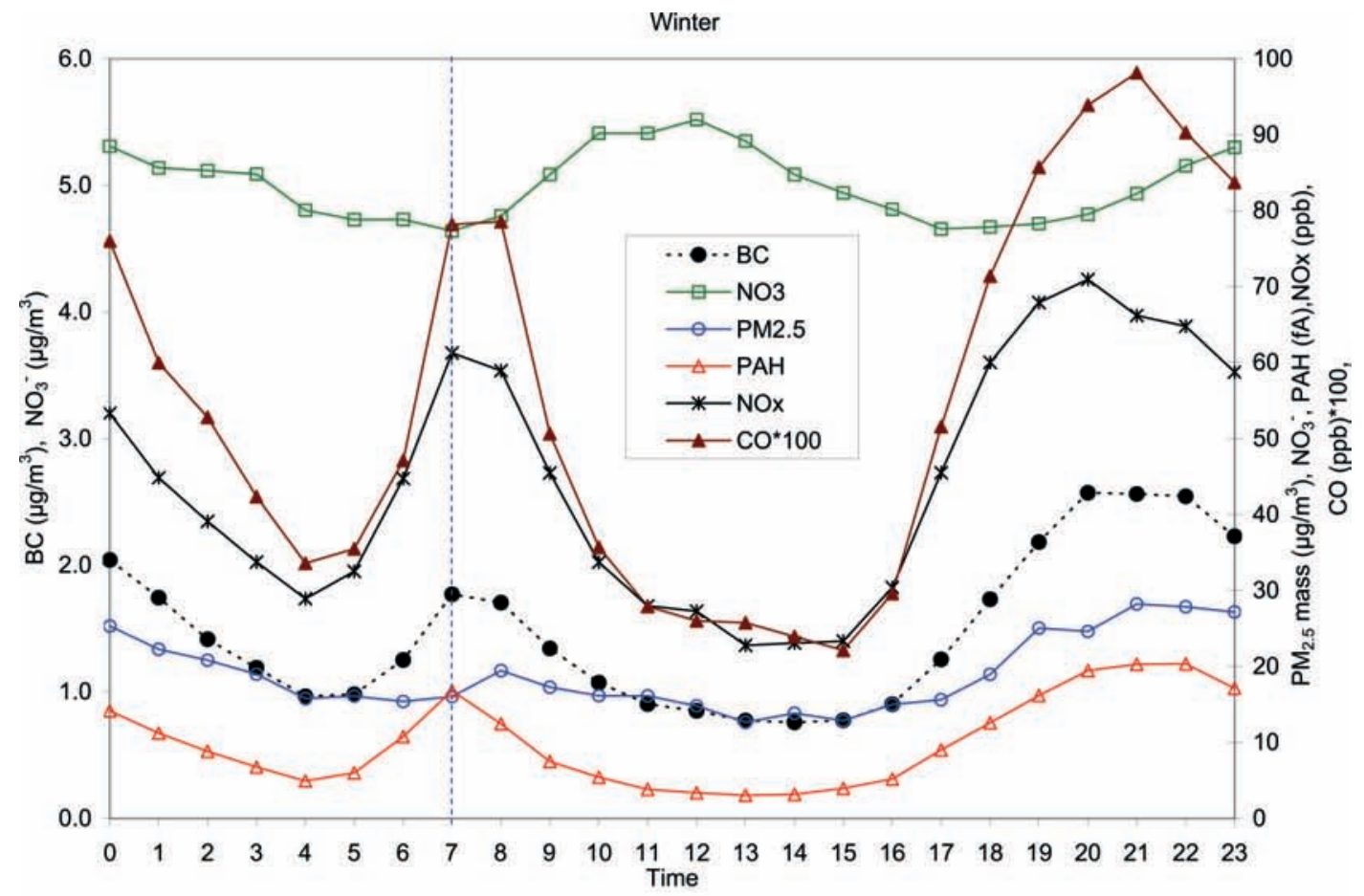

(a)

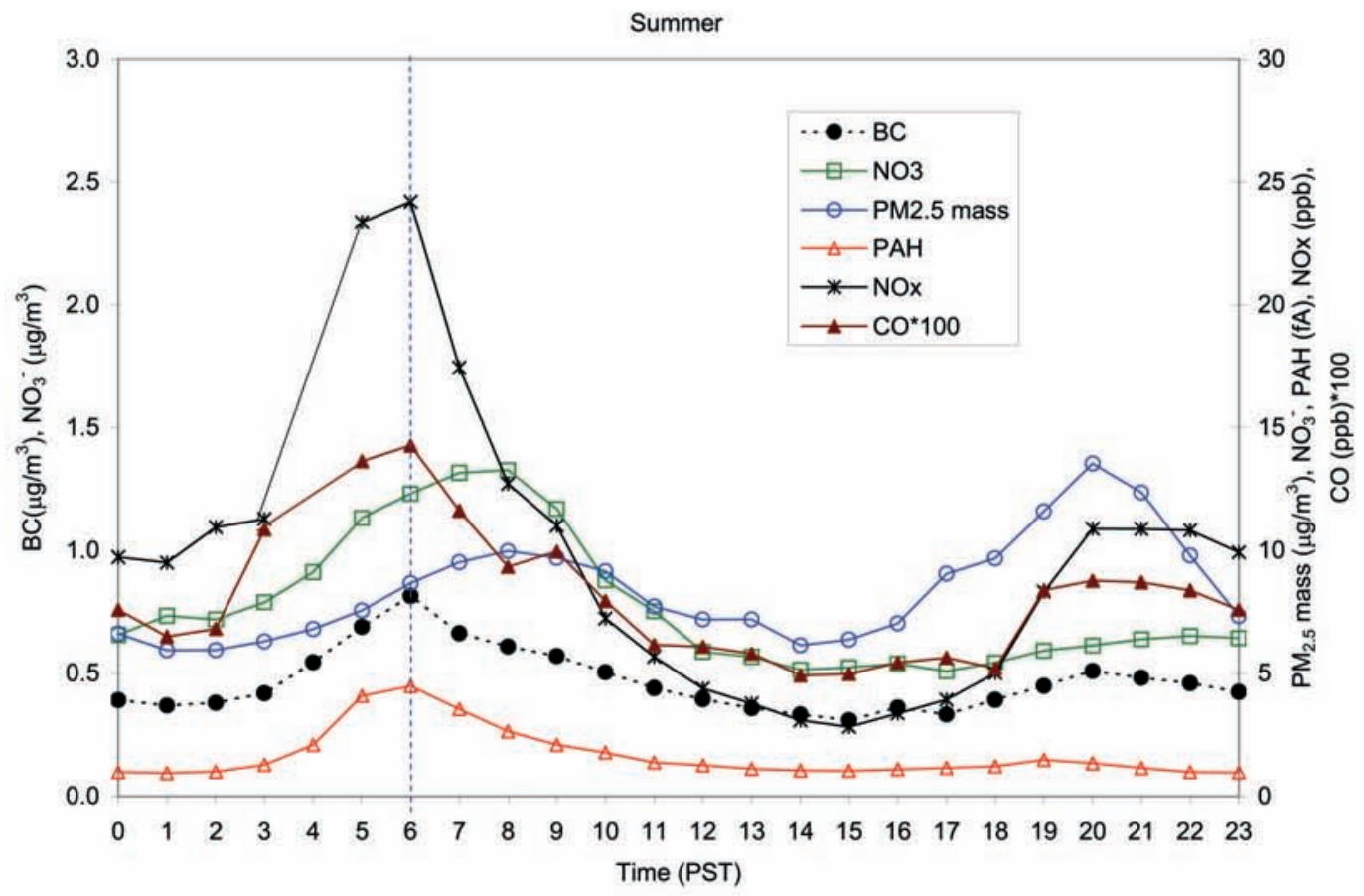

(b)

Figure 9. Diurnal variations of $\mathrm{BC}, \mathrm{NO}_{3}{ }^{-}, \mathrm{PM}_{2.5}$ mass, particle-bound $\mathrm{PAHs}, \mathrm{NO}_{\mathrm{x}}$, and $\mathrm{CO}$ averaged by the time of day for (a) winter (December 2003 to February 2004) and (b) summer (June to August 2004) 